Supplement of Geosci. Model Dev., 11, 4537-4562, 2018

https://doi.org/10.5194/gmd-11-4537-2018-supplement

(C) Author(s) 2018. This work is distributed under

the Creative Commons Attribution 4.0 License.

(c) (1)

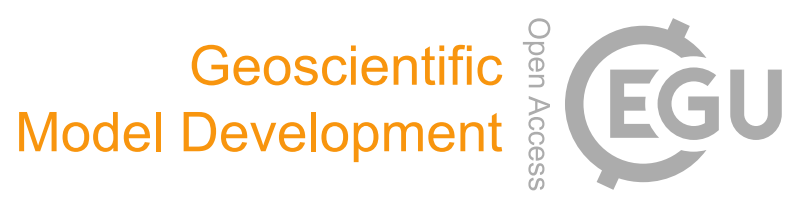

Supplement of

\title{
A protocol for an intercomparison of biodiversity and ecosystem services models using harmonized land-use and climate scenarios
}

HyeJin Kim et al.

Correspondence to: Henrique M. Pereira (hpereira@idiv.de) and HyeJin Kim (hyejin.kim@idiv.de)

The copyright of individual parts of the supplement might differ from the CC BY 4.0 License. 


\section{Supplement}

\section{Supplementary Methods: Description of the post-processing (downscaling) of LUH2 using GLOBIO 4}

\section{GLOBIO 4 discrete land-use allocation routine}

The GLOBIO4 land-use allocation procedure requires two main inputs: regionally aggregated totals or demands ('claims') of each land-use type and, for each land-use type, a layer quantifying the suitability of each grid cell for that land-use type (10 arc-seconds resolution; $~ 300$ $\mathrm{m})$. Claims can be derived from national or regional statistics or from models that estimate demands based on socio-economic developments, for example integrated assessment models (IAMs). All claims are expressed in terms of area $\left(\mathrm{km}^{2}\right)$. The allocation algorithm then prioritizes candidate grid cells according to their suitability values and allocates the claims of each land-use type in each region starting from the cells with the highest suitability until the total claim is allocated. In the allocation a predefined order is followed, where urban land takes precedence over cropland (Bren d'Amour et al., 2017) and cropland in turn takes precedence over pasture (Hasegawa et al., 2017). If for a given land-use type in a given region there are multiple cells with the same suitability, the allocation is done randomly. Non-allocated areas are assigned the primary vegetation type from a natural land cover map. If the area of land use allocated in a given time step is smaller than the area allocated in the preceding time step, the cells that fall free are assigned secondary vegetation.

\section{Suitability layers}

\section{Urban}

Urban claims are first allocated to existing urban area, from the centre outward, and then to non-urban area with the probability decreasing with increasing distance from urban areas. We further assume that within protected areas no further urban expansion takes place (beyond the current urban area in PA). To achieve this, the urban suitability layer is calculated as follows, based on the ESA CCI-LC map for 2005:

- For each urban cell (class 190; see Table A2), calculate the Euclidian distance to the nearest other cell (such that cells in the city centres get higher values than cells near the edges). Normalize such that each value ranges between 0 and 1 , and add +1 to all values. This gives layer 1 .

- For each non-urban cell, calculate the Euclidian distance to the nearest urban cell. Invert the distances (such that cells closer to urban get higher suitability) and normalize such that each value ranges between 0 and 1 . Set values within protected areas to zero. This gives layer 2 .

- Sum the two layers and normalize again such that each cell gets a value between 0 and 1 . This gives a layer where suitability within urban is always higher than beyond urban, and with suitability decreasing from the existing city centres outward.

\section{Cropland}

Similar to urban, cropland is first allocated to existing cropland and then with increasing distance to it (based on ESA CCI-LC map for 2005). We assume that homogeneous cropland cells in the ESA CCI-LC map represent more suitable areas than mosaic croplands. We further assume that within protected areas no further cropland expansion takes place (beyond the current cropland within PA). To achieve this, the suitability layer is calculated as follows:

- For each homogeneous cropland cell in the ESA CCI-LC map for 2005 (classes 10, 11, 12 and 20), calculate the Euclidian distance to the nearest other cell (such that cells in the centres of cropland areas get higher values than cells near the edges). Normalize such that each value ranges between 0 and 1 , and add +2 to all values. This gives layer 1 .

- For each mosaic cropland cell in the ESA CCI-LC map for 2005 (classes 30 and 40), calculate the Euclidian distance to the nearest other cell (such that cells in the centres of cropland areas get higher values than cells near the edges). Normalize such that each value ranges between 0 and 1 , and add +1 to all values. This gives layer 2 .

- For each non-cropland cell, calculate the Euclidian distance to the nearest cropland cell (classes 10, 11, 12, 20, 30 and 40). Invert the distances (such that cells closer to cropland get higher suitability) and normalize such that each value ranges between 0 and 1 . Set values within protected areas to zero. This gives layer 3 .

- Sum the three layers and normalize again such that each cell gets a value between 0 and 1 . This gives a layer where suitability within cropland is always higher than beyond cropland, with homogeneous cropland being more suitable than mosaic cropland, and with suitability decreasing away from existing cropland.

\section{Pasture and rangeland}

For pasture and rangeland, we assume that suitability can be inferred from the density of grazing livestock species, which we retrieve from FAO's gridded livestock of the world (30 arc-seconds). We establish the suitability layer as follows:

- Retrieve the densities (head per $\mathrm{km}^{2}$ ) of each of three ruminant livestock species (cattle, goat, sheep) from the FAO's gridded livestock of the world, resolution 30 arc-seconds (https://livestock.geo-wiki.org/download/).

- To correct for differences in body mass among livestock species, convert heads to so-called tropical livestock units (TLU) by assuming that goat/sheep $=0.1$ TLU and cattle $=0.6$ TLU per individual (Petz et al., 2014). 
- Sum the TLUs per grid and normalize the resulting values to achieve suitabilities ranging from 0 to 1 .

\section{Forestry}

In a recent review it was found that six factors were consistently associated with higher deforestation (roads, urban areas, population, soil suitability, agricultural activity, and proximity to agriculture) (Busch and Ferretti-Gallon, 2017). We assume here that the last five factors primarily reflect deforestation for urban and agricultural development, which is covered in the allocation of urban and cropland, and that forestry/wood harvest is primarily determined by elevation and the proximity to infrastructure needed to transport wood (FAO, 2000). The review further found that protected areas consistently result in lower deforestation. Suitability for forestry (within forest) is therefore calculated as follows:

- Calculate the Euclidian distance to roads from PBL's GRIP database (Meijer et al., accepted) or, in South-America, the distance to either roads or rivers (FAO, 2000), using the Digital Chart of the World (DCW) combined with the Global Lake and Wetland Database (GLWD) to delinate the rivers. Invert and normalize the distances to arrive at suitability values between 0 and 1 . This gives layer 1 .

- Invert and normalize elevation to arrive at suitability values between 0 and 1 . This gives layer 2 .

- Multiply the layers and normalize again to arrive at an overall suitability between 0 and 1 .

Perform the following post-processing steps:

- Set suitability values within protected areas to zero.

- Clip the global suitability layer to land cover with trees from the ESA CCI-LC map for 2005 (classes 50-110; see Table A2). This contains both closed and open forest, in order to accommodate wood harvest from areas with different tree densities (forested and nonforested in LUH2).

\section{Post-processing LUH2 data with the GLOBIO 4 land allocation routine}

\section{Step 1 Discrete allocation of urban, cropland, pasture and forestry}

We use the GLOBIO routine to post-process (downscale) the LUH2 data (http://luh.umd.edu/data.shtml) and refine for cropland, as follows:

1) We aggregated the areas of urban, cropland, pasture, rangeland and forestry across the LUH2 cells to IMAGE region level to obtain the claims. The cropland claim consists of the sum of the five cropland types $(c 3 a n n+c 3 p e r+c 4 a n n+c 4 p e r+c 3 n f x)$. The forestry claim is the sum of the wood harvest from forested cells and non-forested cells with primary vegetation (primf_harv + primn_harv), as this is most important for the biodiversity impact. We compiled five sets of claims: three scenarios SSP1-2050, SSP3-2050 and SSP5-2050), the base year (2015), and a starting year (2005) to calculate the initial map.

2) We create an initial land-use map by allocating urban, cropland, pasture, rangeland and forestry with GLOBIO 4 land allocation routine, using the claims for 2005 and, for the primary vegetation, the ESA CCI-LC map for the same year. For pasture and rangeland, we use the same suitability layer. By allocating pasture first and rangeland thereafter, the pasture (more intense use) will be allocated to the most suitable areas. Post-process the initial map to remove any remaining urban (class 190) or cropland (classes 10-40) from the ESA CCI-LC map by reclassifying into secondary vegetation.

3) We then allocated the LUH2 'claims' for the years 2015 and 2050 with the GLOBIO 4 allocation routine, using the map from step 2 as initial land-use map.

\section{Step 2 | Differentiate cropland}

After allocation, we differentiate cropland intensities based on the amount of fertilizer:

1) We created a total fertilizer map layer $(0.25$ degree resolution; $\mathrm{kg} \mathrm{N}$ per ha) as weighted average over the crop types: (fertl_c3ann * c3ann + fertl_c4ann * c4ann + fertl_c3per * c3per + fertl_c4per * c4per + fertl_c3nfx * c3nfx $) /(c 3 a n n+c 4 a n n+c 3 p e r+c 4 p e r+$ c3nfx)

2) We classified intensity per cell: low intensity $=0-100 \mathrm{~kg} \mathrm{~N}$-input/ha, medium intensity $=100-250 \mathrm{~kg}$ N-input $/$ ha and high intensity $=$ $>250 \mathrm{~kg} \mathrm{~N}$-input/ha (Temme and Verburg, 2011).

3) We combined the intensity layer with the map resulting from the discrete allocation to classify cropland based on intensity (postprocessing step). 
Table S1: Sources and characterization of input data in BES-SIM.

\begin{tabular}{|c|c|c|c|}
\hline $\begin{array}{l}\text { BES-SIM } \\
\text { model }\end{array}$ & $\begin{array}{l}\text { Land-use data - re-categorization of LUH2 } \\
\text { land-use classes in the model }\end{array}$ & $\begin{array}{l}\text { Climate data - data sources with } \\
\text { variables used in the model }\end{array}$ & Other data \\
\hline \multicolumn{4}{|c|}{ Species-based models of biodiversity } \\
\hline $\begin{array}{l}\text { AIM- } \\
\text { biodiversity }\end{array}$ & $\begin{array}{l}\text { Cropland (c3ann, c4ann, c3per, c4per, c3nfx) } \\
\text { Pasture (pastr) } \\
\text { Built-up area (urban) } \\
\text { Forest (primf, secdf) } \\
\text { Other natural land (primn, secdn, range) }\end{array}$ & $\begin{array}{l}\text { ISIMIP2a (IPSL-CM5a-LR) } \\
\text { - monthly mean maximum } \\
\text { temperature, monthly mean } \\
\text { minimum temperature, } \\
\text { monthly precipitation }\end{array}$ & $\begin{array}{l}\text { Species occurrence records } \\
\text { (GBIF) }\end{array}$ \\
\hline InSiGHTS & $\begin{array}{l}\text { Cropland (c3ann, c3per, c3nfx, c4ann, c4per) } \\
\text { Forest (primf, secdf) } \\
\text { Non-forest (primn, secdn, range) } \\
\text { Pasture (pastr) } \\
\text { Urban (urban) }\end{array}$ & $\begin{array}{l}\text { WorldClim v1 } \\
\text { - annual mean temperature, } \\
\text { diurnal range (mean of monthly), } \\
\text { isothermality, temperature } \\
\text { seasonality, max temperature of } \\
\text { warmest month, minimum } \\
\text { temperature of coldest month, } \\
\text { temperature annual range, mean } \\
\text { temperature of wettest, driest, } \\
\text { warmest quarter, and coldest } \\
\text { quarters, annual precipitation, } \\
\text { precipitation of wettest and driest } \\
\text { months, seasonality, wettest, } \\
\text { driest, warmest, and coldest } \\
\text { quarters }\end{array}$ & $\begin{array}{l}\text { Global mammal habitat suitability } \\
\text { models (Rondinini et al., 2011) } \\
\text { Mammal range maps (IUCN) }\end{array}$ \\
\hline MOL & $\begin{array}{l}\text { Forest (primf, secdf) } \\
\text { Grassland/shrubland/wetland (secdf, secdn) } \\
\text { Rangeland (pastr, range) } \\
\text { Urban (urban) } \\
\text { Crops (c3ann, c3per, c3nfx, c4ann, c4per) }\end{array}$ & $\begin{array}{l}\text { WorldClim v2 (present), v1.4 } \\
\text { (future) } \\
\text { - annual mean temperature, } \\
\text { temperature seasonality, annual } \\
\text { precipitation, precipitation } \\
\text { seasonality, precipitation of driest } \\
\text { quarter }\end{array}$ & $\begin{array}{l}\text { Expert maps (IUCN) } \\
\text { Species land cover preferences } \\
\text { drawn from the literature }\end{array}$ \\
\hline \multicolumn{4}{|c|}{ Community-based models of biodiversity } \\
\hline cSAR-iDiv & $\begin{array}{l}\text { Primary vegetation (primf, primn } \\
\text { Secondary vegetation (secdf, secdn) } \\
\text { Pasture (pastr, range) } \\
\text { Urban (urban) } \\
\text { Cropland (c3ann, c4ann, c3nfx) } \\
\text { Permanent (c3per, c4per) }\end{array}$ & & $\begin{array}{l}\text { Bird species occurrence data } \\
\text { (Birdlife International) } \\
\text { Coefficients for affinities } \\
\text { (PREDICTS) }\end{array}$ \\
\hline
\end{tabular}




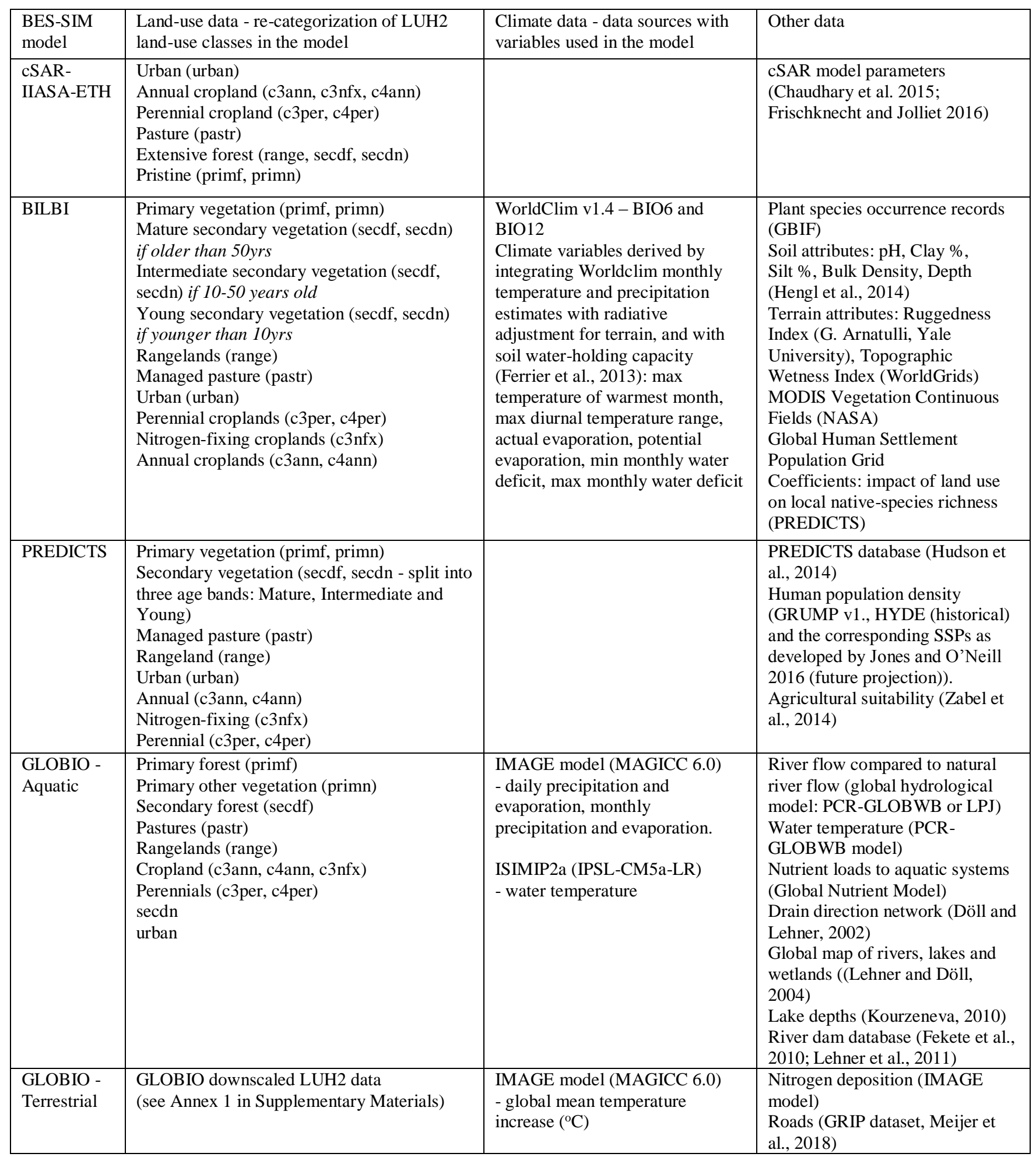




\begin{tabular}{|c|c|c|c|}
\hline $\begin{array}{l}\text { BES-SIM } \\
\text { model }\end{array}$ & $\begin{array}{l}\text { Land-use data - re-categorization of LUH2 } \\
\text { land-use classes in the model }\end{array}$ & $\begin{array}{l}\text { Climate data - data sources with } \\
\text { variables used in the model }\end{array}$ & Other data \\
\hline & & & $\begin{array}{l}\text { Settlements in tropical regions } \\
\text { (Humanitarian Data Exchange, } \\
\text { Open Street Map) }\end{array}$ \\
\hline \multicolumn{4}{|c|}{ Ecosystems-based model of biodiversity } \\
\hline Madingley & $\begin{array}{l}\text { States } \\
\text { Primary (primf, primn) } \\
\text { Secondary (secdf, secdn) } \\
\text { Grazing (pastr, range) } \\
\text { Cropland (c3ann, c4ann, c3per, c4per, c3nfx) } \\
\text { Urban (urban) } \\
\text { Transitions } \\
\text { Primary losses (all transitions beginning with } \\
\text { primf or primn) } \\
\text { Secondary losses (all transitions beginning } \\
\text { with secdf or secdn) } \\
\text { Secondary gains (all transitions ending with } \\
\text { secdf or secdn) }\end{array}$ & $\begin{array}{l}\text { ISIMIP2a (IPSL-CM5a-LR) } \\
\text { - temperature, precipitation }\end{array}$ & $\begin{array}{l}\text { Soil characteristics (Smith et al., } \\
\text { 2013) } \\
\text { Modis Net Primary Productivity } \\
\text { (NASA, 2012) } \\
\text { Human Appropriation of Net } \\
\text { Primary Productivity (Haberl et } \\
\text { al., 2007) } \\
\text { Human population densities } \\
\text { (Jones and O'Neill, 2016; Klein } \\
\text { Goldewijk et al., 2016)3 }\end{array}$ \\
\hline \multicolumn{4}{|c|}{ Models of ecosystem functions and services } \\
\hline LPJ-GUESS & $\begin{array}{l}\text { Primary natural vegetation (primf, primn) } \\
\text { Secondary natural vegetation (secdf, secdn) } \\
\text { Pasture (pastr, range) } \\
\text { C3 crops (c3ann, c3per, c3nfx) } \\
\text { C4 crops (c4ann, c4per) } \\
\text { Urban (modelled as natural vegetation) }\end{array}$ & $\begin{array}{l}\text { ISIMIP2a (IPSL-CM5a-LR) } \\
\text { - monthly min/max T, } \\
\text { precipitation, shortwave radiation; } \\
\text { atmospheric } \mathrm{CO}_{2}, \mathrm{~N} \text {-input, } \\
\text { fractional land cover (crop } \\
\text { irrigated yes/no, pasture, managed } \\
\text { forest, natural) }\end{array}$ & $\begin{array}{l}\text { Crop irrigated and biofuel } \\
\text { fraction (LUH2 dataset) } \\
\text { Wood harvest estimate (LUH2 } \\
\text { dataset) } \\
\text { Nitrogen deposition (Lamarque et } \\
\text { al., 2011) }\end{array}$ \\
\hline LPJ & $\begin{array}{l}\text { Primary natural vegetation (primf, primn) } \\
\text { Secondary natural vegetation (secdf, secdn) } \\
\text { Pasture (pastr, range, c3ann, c3per, c3nfx, } \\
\text { c4ann, c4per) } \\
\text { urban (modelled as natural vegetation) }\end{array}$ & $\begin{array}{l}\text { ISIMIP2a (IPSL-CM5a-LR) } \\
\text { - monthly T, precipitation, } \\
\text { shortwave radiation or cloudiness; } \\
\text { atmospheric } \mathrm{CO}_{2} \text {, fractional land } \\
\text { cover (pasture, managed forest, } \\
\text { natural) }\end{array}$ & \\
\hline $\begin{array}{l}\text { GLOBIO- } \\
\text { ES }\end{array}$ & $\begin{array}{l}\text { Primary forest (primf) } \\
\text { Primary other vegetation (primn) } \\
\text { Secondary forest (secdf) } \\
\text { Pastures (pastr) } \\
\text { Rangelands (range) } \\
\text { Cropland (c3ann, c4ann, c3nfx) } \\
\text { Perennials (c3per, c4per) } \\
\text { secdn } \\
\text { urban }\end{array}$ & $\begin{array}{l}\text { IMAGE model (MAGICC 6.0) } \\
\text { - aggregated monthly } \\
\text { precipitation, monthly wet day } \\
\text { frequency }\end{array}$ & $\begin{array}{l}\text { Population size, GDP per capita, } \\
\text { soil data, altitude range, slope } \\
\text { (IMAGE model) } \\
\text { Population density in river } \\
\text { floodplains } \\
\text { Water demand for electricity, } \\
\text { industry and households (Bijl et } \\
\text { al., 2016) }\end{array}$ \\
\hline
\end{tabular}




\begin{tabular}{|c|c|c|c|}
\hline $\begin{array}{l}\text { BES-SIM } \\
\text { model }\end{array}$ & $\begin{array}{l}\text { Land-use data - re-categorization of LUH2 } \\
\text { land-use classes in the model }\end{array}$ & $\begin{array}{l}\text { Climate data - data sources with } \\
\text { variables used in the model }\end{array}$ & Other data \\
\hline InVEST & $\begin{array}{l}\text { GLOBIO downscaled LUH2 data } \\
\text { (see Annex } 1 \text { in Supplementary Materials) }\end{array}$ & $\begin{array}{l}\text { Nutrient delivery } \\
\text { WorldClim v1.4 } \\
\text { - precipitation } \\
\\
\text { Coastal Vulnerability } \\
\text { CMIP5 AOGCMs } \\
\text { - sea level rise }\end{array}$ & $\begin{array}{l}\text { Nutrient delivery } \\
\text { Digital elevation model (ASTER) } \\
\text { Biophysical table (InVEST } \\
\text { database) } \\
\text { Rural population scenarios (Jones } \\
\text { and O'Neill, 2016) } \\
\text { Population raster (GPWv4, 2018) } \\
\text { Coastal Vulnerability } \\
\text { Natural Habitat polygons for } \\
\text { mangrove, corals, and eel grass } \\
\text { (WCMC) } \\
\text { Continental Shelf polygon } \\
\text { (COMARGE, Census of Marine } \\
\text { Life) } \\
\text { Digital elevation model (ASTER) } \\
\text { Wind and wave exposure } \\
\text { (WAVEWATCH III) } \\
\text { Population raster (GPWv4 - } \\
\text { 2018) } \\
\text { Pollination } \\
\text { Yield raster for 115 crops } \\
\text { (Monfreda et al., 2008) } \\
\text { Nutrient content of 115 crops } \\
\text { (table; USDA 2011) } \\
\text { Pollination dependence of 115 } \\
\text { crops (Klein et al., 2007) } \\
\text { Dietary requirements (Allen et al., } \\
\text { 2006; BNF, 2016) } \\
\text { Demographic population data } \\
\text { (GPWv4 Age Dataset - 2018) } \\
\text { Crop production } \\
\text {-Yield raster for 115 crops } \\
\text { (Monfreda et al., 2008) }\end{array}$ \\
\hline GLOSP & 12 original land states in LUH2 & $\begin{array}{l}\text { ISIMIP2a (IPSL-CM5a-LR) } \\
\text { - precipitation }\end{array}$ & $\begin{array}{l}\text { Fractional vegetation cover } \\
\text { (Filiponi et al., accepted) } \\
\text { Topography (GMTED2010) } \\
\text { Soil type and physical properties } \\
\text { (Hengl et al., 2014) }\end{array}$ \\
\hline
\end{tabular}


Table S2: Model description, modifications and assumptions made to published models in BES-SIM.

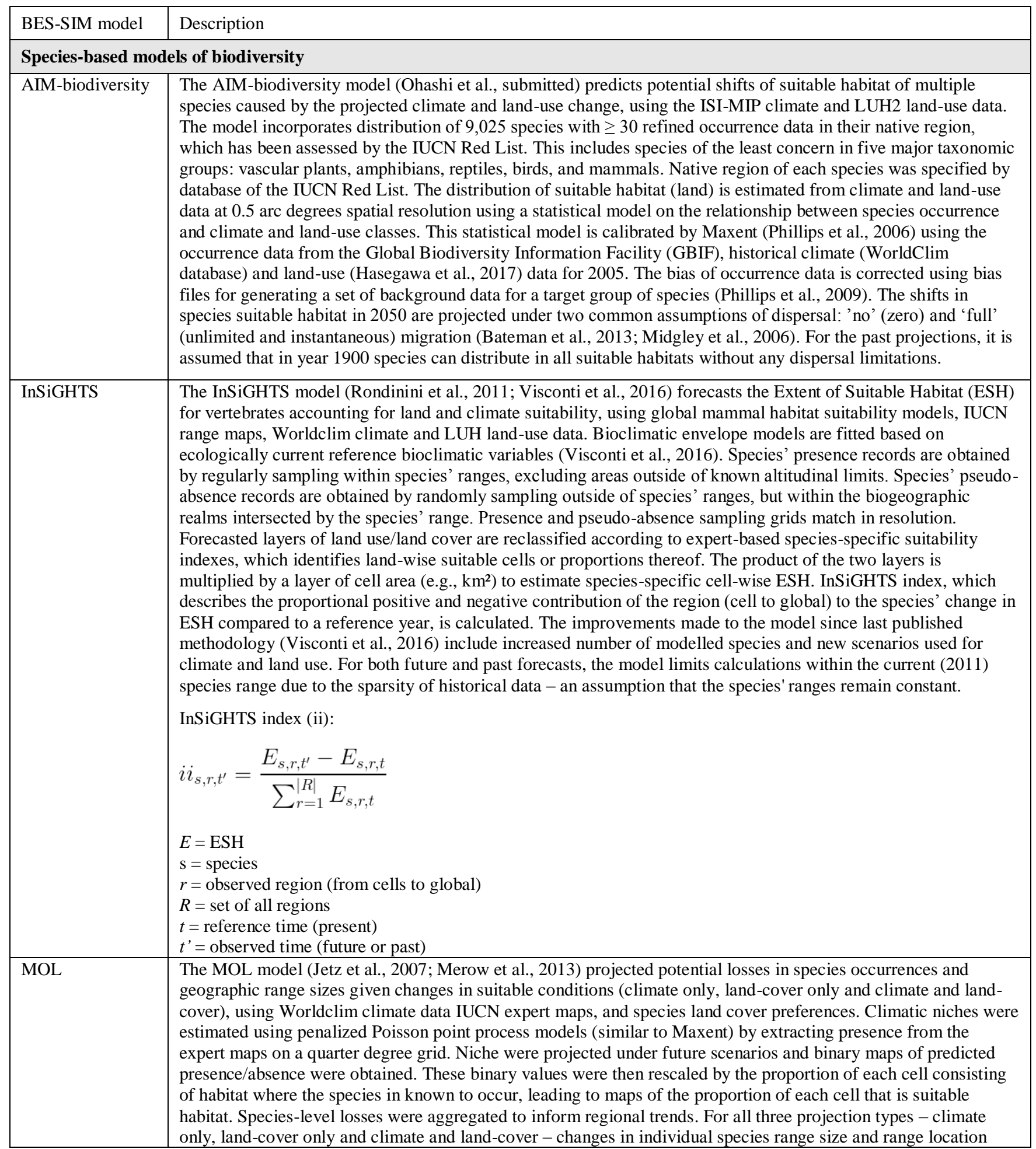




\begin{tabular}{|c|c|}
\hline \multirow[t]{2}{*}{ BES-SIM model } & Description \\
\hline & $\begin{array}{l}\text { were assessed and summarized for different taxonomic and geographic groupings. Species Habitat Index and Red } \\
\text { List Index may be projected with modelled results. All modelling was performed as part of a multispecies } \\
\text { workflow that automates production and quality control for range models. }\end{array}$ \\
\hline BIOMOD2 & $\begin{array}{l}\text { The BIOMOD2 model (Thuiller, 2004; Thuiller et al., 2009, 2011) is an R-package that allows running up to nine } \\
\text { different algorithms of species distribution models using the same data and the same framework. An ensemble is } \\
\text { produced to allow for a full treatment of uncertainties given data, algorithms, climate models and climate } \\
\text { scenarios. Based on the species distribution models that link observed or known presence-absence data to } \\
\text { environmental variables (e.g. climate), each model is cross-validated several times (a random subset of } 70 \% \text { of } \\
\text { data is used for model calibration while } 30 \% \text { is held out for model evaluation). Models are evaluated using various } \\
\text { metrics, and produce indicators including change in species range, species loss and gain per pixel, species } \\
\text { turnover, functional and phylogenetic diversity. }\end{array}$ \\
\hline \multicolumn{2}{|c|}{ Community-based models of biodiversity } \\
\hline cSAR-iDiv & $\begin{array}{l}\text { The cSAR-iDiv (Martins and Pereira, 2017; Pereira and Daily, 2006) model assesses the response of biodiversity } \\
\text { to land-use change, using LUH2 land use, Birdlife species occurrence and PREDICTS affinities data. It accounts } \\
\text { for the persistence of species in human-modified habitats and for the differential use of habitats by species. The } \\
\text { model allows to assess the impact of changes in species richness across scenarios of land use in the countryside } \\
\text { SAR, the richness of each functional species group } i, S_{i} \text {, is given by a function of the area of each habitat } j, A_{j} \text {, in } \\
\text { the landscape, } \\
\qquad S_{i}=c_{i}\left(\sum_{j=1}^{n} h_{i j} A_{j}\right)^{z} \\
\text { where n is the number of modified habitats types, } h_{i j} \text { is the affinity of species group } i \text { to habitat } j \text { and } A_{j} \text { is the area } \\
\text { cover by habitat } j \text {. The parameters } c \text { and } z \text { are constants that depend on the taxonomic group and sampling scheme } \\
\text { respectively, and will be species group dependent. Species are classified in functional species groups sharing } \\
\text { similar habitat preferences using the Birdlife dataset. The } h_{i j} \text {, reflecting the relative affinity of a functional species } \\
\text { group } i \text { to a modified habitat type } j \text { compared to its natural habitat are derived from the PREDICTS dataset. The } \\
\text { model calculates the proportion of species of each functional group between two time periods, then multiplies the } \\
\text { trend by the actual number of species of the functional group (i.e. as reported by Birdlife) in each sampling unit. } \\
\text { Using this approach, the model estimates the trends of local (i.e., grid cells), regional and global species richness } \\
\text { of the two functional groups of bird species - forest and non-forest. The improvements made since last published } \\
\text { methodology include the use of high-resolution land-use dataset and affinities calculated from the PREDICTS } \\
\text { dataset, and application of two functional groups across scales based on habitat types (land classification). For the } \\
\text { past projections, the model is applied starting from } 1900 \text { with an assumption that the number of species currently } \\
\text { present in different areas/sampling units (IUCN/Birdlife data) corresponds to the number of species at the starting } \\
\text { point. }\end{array}$ \\
\hline $\begin{array}{l}\text { cSAR-IIASA- } \\
\text { ETH }\end{array}$ & $\begin{array}{l}\text { The IIASA-ETH cSAR model is based on a countryside Species Area Relationship (cSAR) type of model and } \\
\text { estimates the impact of time series of spatially explicit land-use and land-cover transitions on community-level } \\
\text { measures of terrestrial biodiversity on five taxa (amphibians, birds, mammals, reptiles and plants). It uses LUH2 } \\
\text { data and the initial species richness and cSAR model parameters from Chaudhary et al. (2015) and Frischknecht } \\
\text { and Jolliet (2016). Regional species loss is weighted by the fraction of range area of all species in every ecoregion } \\
\text { and IUCN threat level, to derive an estimate of global extinctions. } \\
\text { The original approach of Chaudhary et al. (2015) is not tailored for estimating long-term and large land-use } \\
\text { changes because i) it is a linear approximation (contingent to the current land-use patterns) of a non-linear } \\
\text { relationship, and ii) although it incorporates a measure of the length of recovery, the approach is not designed to } \\
\text { look at the dynamics of LULCC towards a more biodiversity-friendly state. Instead, in the IIASA-ETH-cSAR } \\
\text { model the biodiversity impacts of land-use change is estimated directly from the cSAR formula (cSAR } \\
\text { relationship and parameters for the model) and applied to the land-use shares for the various LULC classes } \\
\text { considered (their affinity values are derived directly for the local characterization factor database based on field } \\
\text { records). The link between LULCC and habitat is more detailed by taking the gross transitions directly as input }\end{array}$ \\
\hline
\end{tabular}




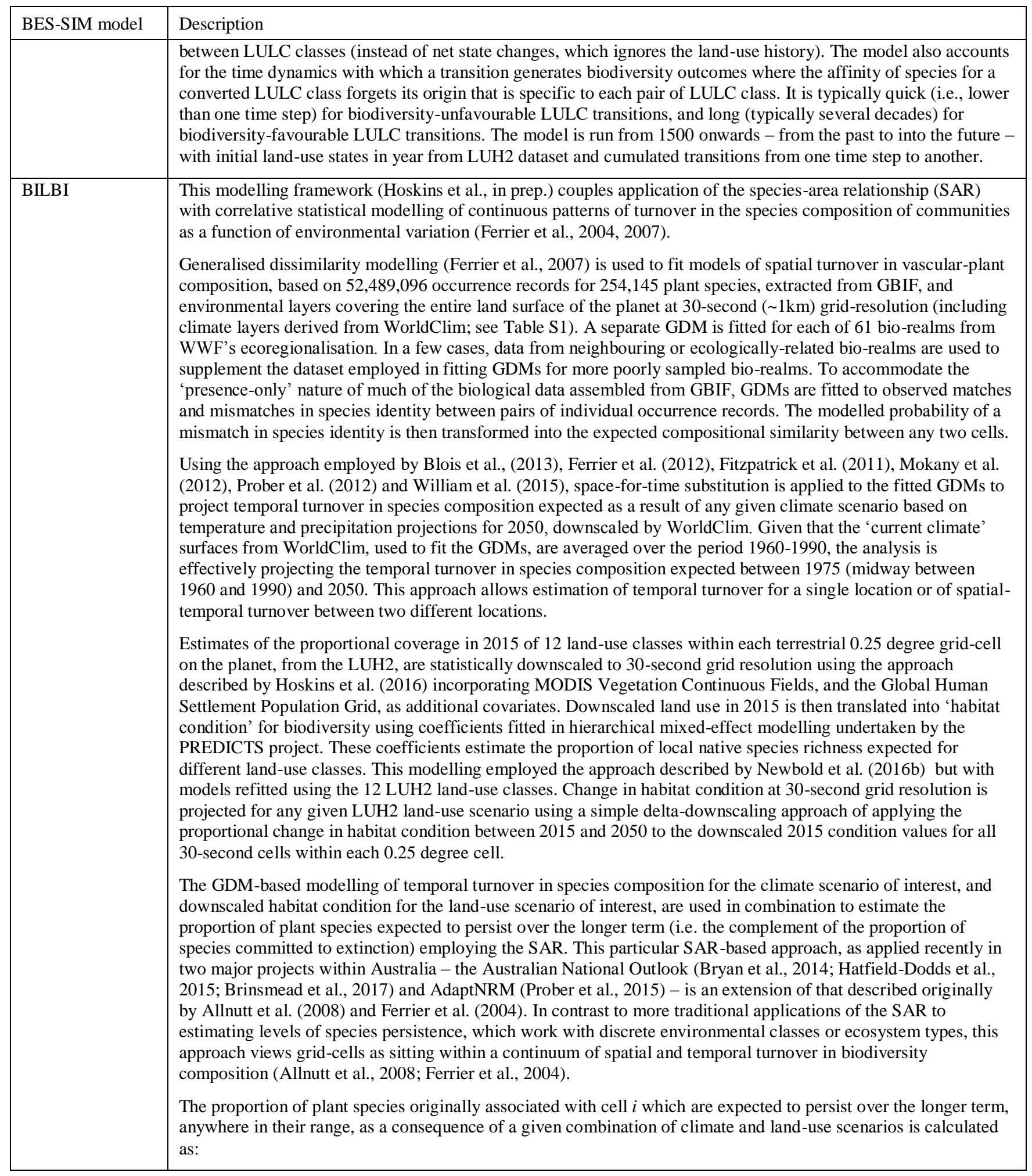




\begin{tabular}{|c|c|}
\hline BES-SIM model & Description \\
\hline & 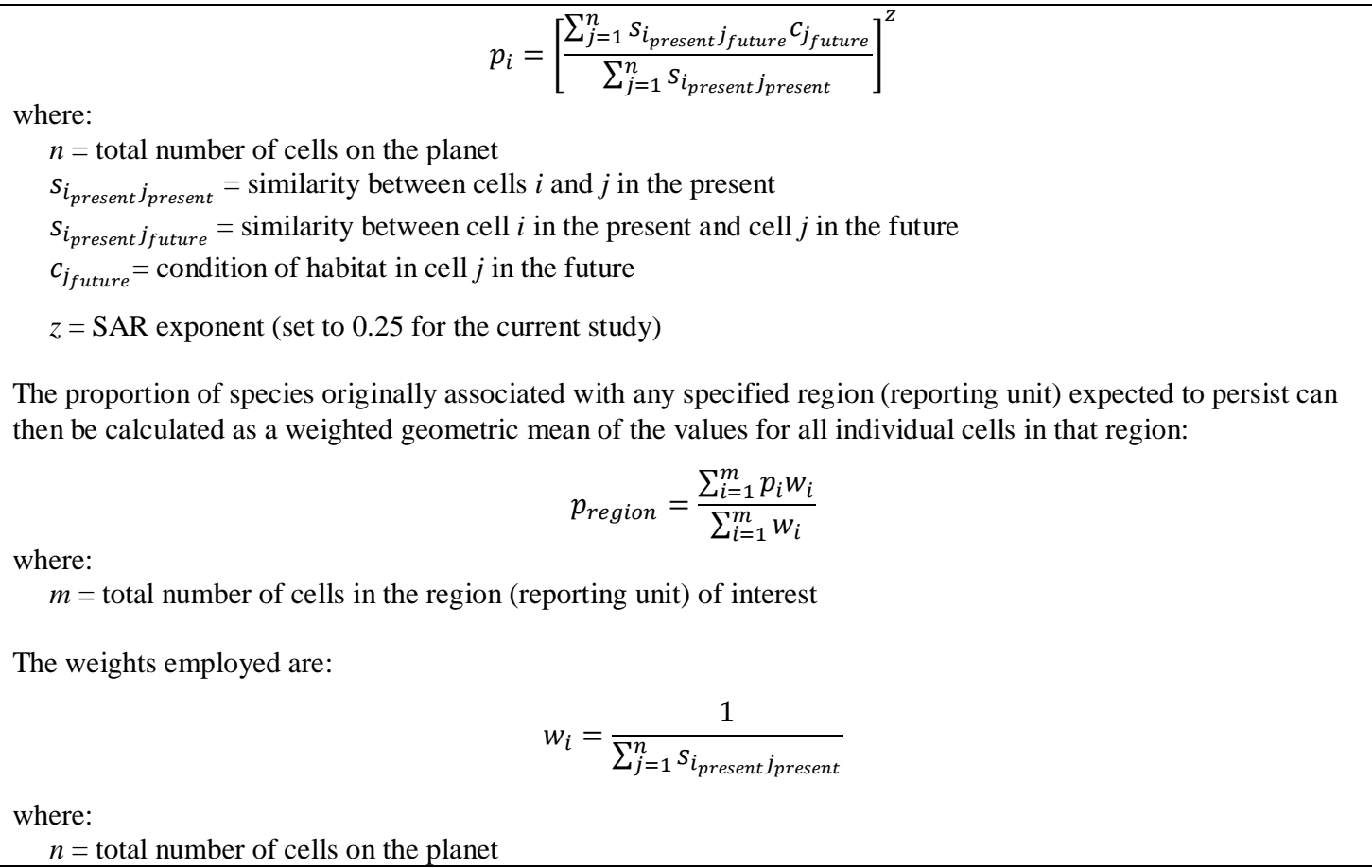 \\
\hline PREDICTS & 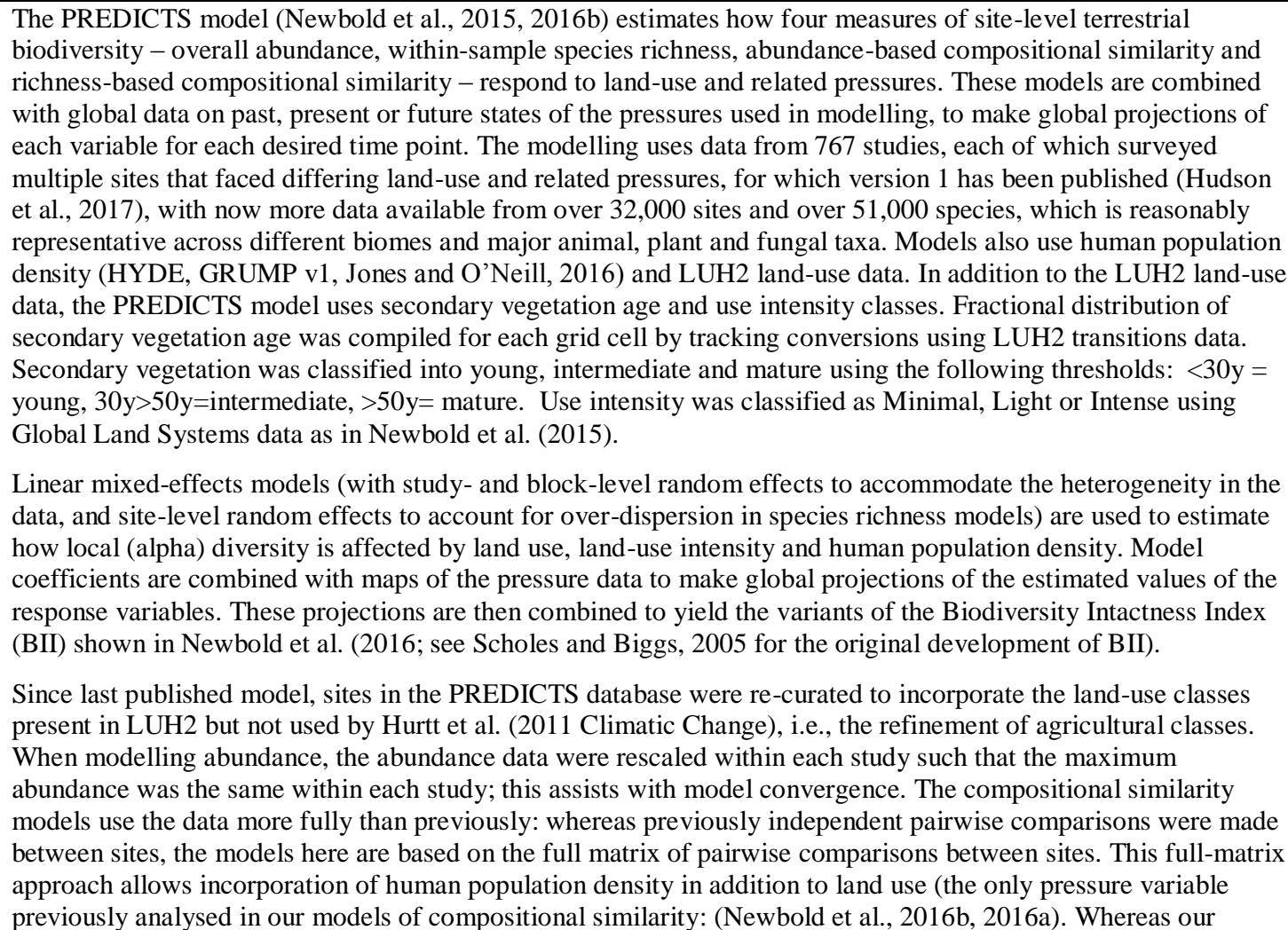 \\
\hline
\end{tabular}




\begin{tabular}{|c|c|}
\hline BES-SIM model & Description \\
\hline & $\begin{array}{l}\text { previous models of compositional similarity used all primary vegetation sites as the baseline condition, expansion } \\
\text { of the database has allowed us to restrict the baseline to minimally-used primary vegetation. Previously, human } \\
\text { population density (ln(x+1)-transformed) was fitted as a quadratic term in models of abundance and richness but } \\
\text { omitted from models of compositional similarity; here we have treated it as a linear term in all models to improve } \\
\text { consistency. The study-level mean of ln(human population density + 1) was also added as a control variable into } \\
\text { the models of abundance and species-richness, to avoid possible artefacts that could otherwise arise if studies in } \\
\text { more densely-populated areas sample more intensively. Agricultural suitability (Zabel et al., 2014) was also used } \\
\text { as a control variable (Gray et al., 2016). These control variables are used as additive terms in modelling but not } \\
\text { projections. Our previous models of abundance and richness considered proximity to roads as a pressure, but we } \\
\text { have omitted roads from these models because of the lack of future and historical estimates; land use, land-use } \\
\text { intensity and human population density - all somewhat correlated with proximity to roads - have the potential to } \\
\text { explain some of the variance previously explained by roads. } \\
\text { PREDICTS also modelled species richness as a function of land use, in order to provide habitat coefficient } \\
\text { estimates to other models in BES-SIM. Separate models were run for areas that would naturally be forested and } \\
\text { non-forested (data subset using LUH2/fstnf). Human population density was omitted from the model; otherwise, } \\
\text { model structure matched that outlined above. }\end{array}$ \\
\hline GLOBIO-Aquatic & $\begin{array}{l}\text { The GLOBIO-Aquatic model (Janse et al., 2015) quantifies the impacts of multiple anthropogenic pressures in the } \\
\text { past, present and future on freshwater biodiversity and its ecosystem services, using climate (IMAGE model), land } \\
\text { use (GLOBIO model), river flow (PCR-GLOBWB or LPJ model), water template (PCR-GLOBWB model), } \\
\text { nutrient loads to aquatic systems (Global Nutrient Model), global map of rivers, lakes and wetlands (GLWD), and } \\
\text { river dam database. The drivers included are land use, eutrophication, climate change and hydrological } \\
\text { disturbance. The model comprises a set of mostly correlative relationships between anthropogenic drivers and } \\
\text { biodiversity and ecosystem services of rivers, lakes and wetlands. The model produces biodiversity intactness } \\
\text { indicator - Mean Species Abundance (MSA) - of lakes, rivers and wetlands as well as the probability of harmful } \\
\text { algal blooms as an indicator for freshwater provisioning services. }\end{array}$ \\
\hline $\begin{array}{l}\text { GLOBIO- } \\
\text { Terrestrial }\end{array}$ & $\begin{array}{l}\text { The GLOBIO model for terrestrial biodiversity (Alkemade et al., 2009) quantifies the impacts of multiple } \\
\text { anthropogenic pressures on local biodiversity based on the mean species abundance (MSA) metric. MSA } \\
\text { represents the mean abundance of original species in relation to a particular pressure as compared to the mean } \\
\text { abundance in an undisturbed reference situation. MSA's responses to a particular pressure are quantified based on } \\
\text { a meta-analysis of biodiversity monitoring data reported in the literature, whereby abundance ratios of individual } \\
\text { species are calculated as } A_{\text {impacted }} \mathrm{A}_{\text {reference }} \text { for } \mathrm{A}_{\text {impacted }}<\mathrm{A}_{\text {reference }} \text { and } \mathrm{A}_{\text {impacted }} / \mathrm{A}_{\text {reference }}=1 \text { for } \mathrm{A}_{\text {impacted }}>\mathrm{A}_{\text {reference. }} \\
\text { Changes in biodiversity are quantified by combining georeferenced layers of the pressure variables with the MSA } \\
\text { response relationships. Next, the maps with the MSA values per pressure are combined to arrive at an overall } \\
\text { MSA. If a particular pressure is assumed to be dominant, the combined impact (MSA) is assumed equal to the } \\
\text { impact (MSA) of this dominant pressure. If pressures act independently, the overall MSA value is calculated by } \\
\text { multiplying the MSA values corresponding with the individual pressures. } \\
\text { Five pressures are currently included (climate change, land use, roads, atmospheric nitrogen deposition and } \\
\text { encroachment/hunting). Climate change, nitrogen deposition, and land-use data are derived from the IMAGE } \\
\text { model (Stehfest et al., } 2014 \text { ). Land-use data from IMAGE are downscaled to a higher spatial resolution with the } \\
\text { GLOBIO land allocation routine. Roads data are taken from the global road inventory project (GRIP) database } \\
\text { (Meijer et al., submitted). Settlement data (required to calculate hunting impacts) are retrieved from multiple open- } \\
\text { source datasets, including Open Street Map and Humanitarian Data Exchange. } \\
\text { Improvements made to the model since the last published methodology include a new high-resolution, discrete } \\
\text { land-use allocation routine and improved response relationships for encroachment/hunting (Benítez-López et al., } \\
\text { 2017). }\end{array}$ \\
\hline
\end{tabular}




\begin{tabular}{|c|c|}
\hline BES-SIM model & Description \\
\hline Madingley & 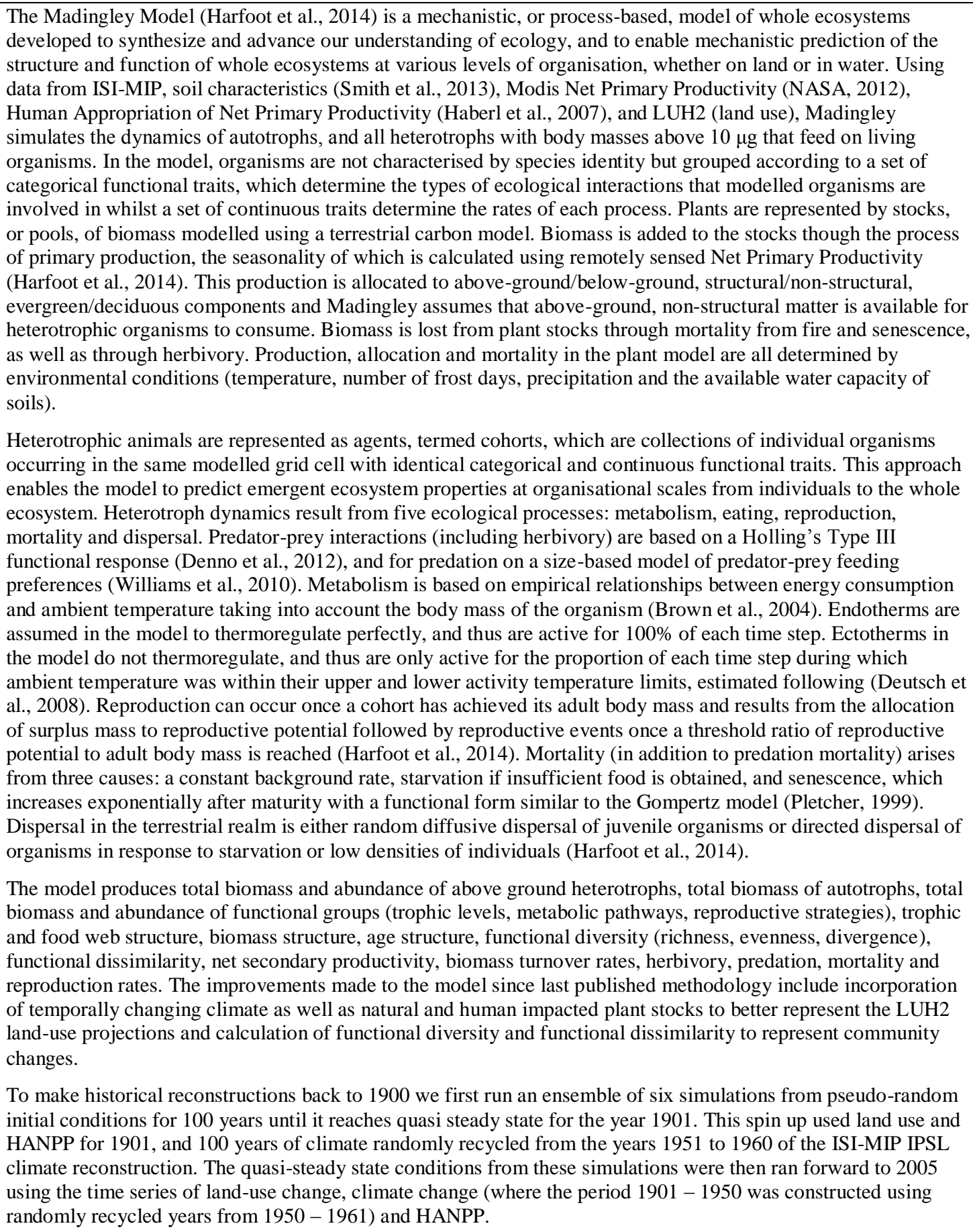 \\
\hline \multicolumn{2}{|c|}{ Models of ecosystem functions and services } \\
\hline LPJ-GUESS & $\begin{array}{l}\text { The LPJ-GUESS model (Lindeskog et al., 2013; Olin et al., 2015; Smith et al., 2014) is a "demography enabled" } \\
\text { dynamic global vegetation model using historical and future climate, } \mathrm{CO}_{2} \text {, nitrogen deposition and fertilizer, land }\end{array}$ \\
\hline
\end{tabular}




\begin{tabular}{|c|c|}
\hline BES-SIM model & Description \\
\hline & $\begin{array}{l}\text { cover change, irrigated fraction, and wood harvest estimate data. The model computes vegetation and soil state } \\
\text { and function, and distribution of vegetation units dynamically in space and time in response to climate change, } \\
\text { land-use change, atmospheric } \mathrm{CO}_{2} \text {, and N-input. It combines an individual- and patch-based representation of } \\
\text { vegetation dynamics with ecosystem biogeochemical cycling from regional to global scales. In LPJ-GUESS, the } \\
\text { dynamics of vegetation result from growth and competition for space, light, and soil resources from herbaceous } \\
\text { understorey and woody plant individuals in each patch replicated for each simulated grid cell. The suite of } \\
\text { simulated patches represents the distribution within a landscape representative of the grid cell as a whole of } \\
\text { vegetation stands with different histories of disturbance and stand development (succession). Individuals for } \\
\text { woody plant functional types (PFTs; trees and shrubs) are identical within a cohort (age/size class) and patch. } \\
\text { Photosynthesis, respiration, stomatal conductance and phenology (leaves and fine roots turnover) are simulated on } \\
\text { a daily time step. The net primary production (NPP) accrued at the end of each simulation year is allocated to } \\
\text { leaves, fine roots and, for woody PFTs, sapwood, following a set of prescribed allometric relationships for each } \\
\text { PFT, resulting in diameter, height, and biomass growth. Population dynamics (establishment and mortality) are } \\
\text { represented as stochastic processes, influenced by current resource status, demography and the life-history } \\
\text { characteristics of each PFT (text from Smith et al., 2014). The modelled outputs include carbon pools in } \\
\text { vegetation, soil, gross primary productivity, heterotrophic respiration, net primary productivity, runoff, leaf area } \\
\text { index, crop yields, area burnt, fire emissions, carbon to nitrogen ratios, and nitrogen loss. The improvements made } \\
\text { since last published methodology include an upgrade in the fire model and accounting for wood harvest. To } \\
\text { provide climate input before } 1951 \text { random years out of the period } 1951 \text { to } 1960 \text { are chosen to generate/recycle the } \\
\text { climate data for years } 1901 \text { to } 1950 \text {. }\end{array}$ \\
\hline LPJ & 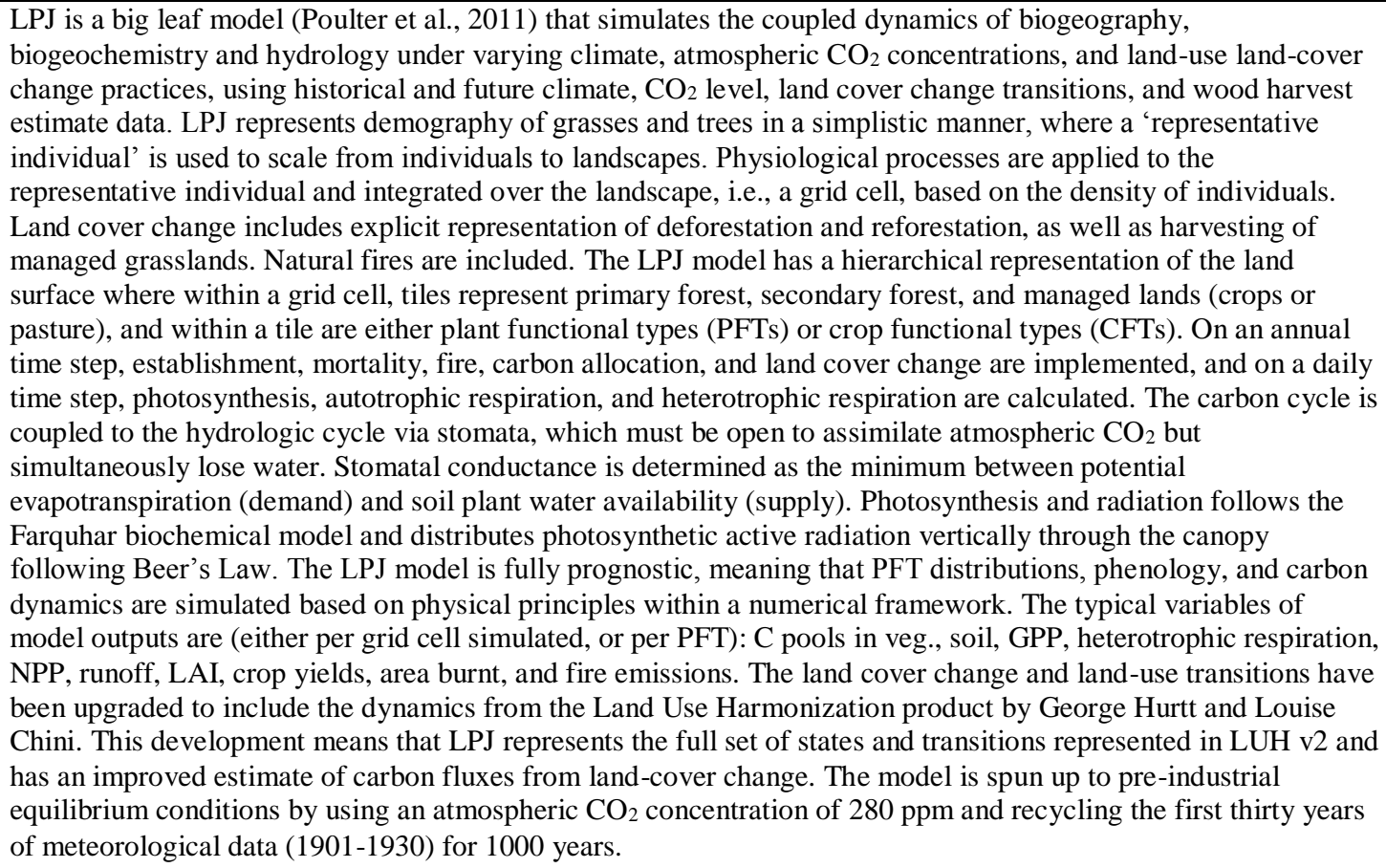 \\
\hline CABLE & $\begin{array}{l}\text { CABLE is a "demography enabled" global terrestrial biosphere model (Haverd et al., 2017) that computes } \\
\text { vegetation and soil state and function dynamically in space and time in response to climate change, land-use } \\
\text { change and N-input, using historical and future daily climate data downscaled to } 3 \text {-hourly, annual } \mathrm{CO}_{2} \text { levels in } \\
\text { the atmosphere, N-deposition, land-cover change, irrigated faction, and wood harvest area. It combines a patch- } \\
\text { based representation of vegetation structural dynamics with ecosystem biogeochemical cycling from regional to } \\
\text { global scales. CABLE consists of a 'biophysical' core, the CASA-CNP 'biogeochemistry' module (Wang et al., } \\
\text { 2010) and the POP module for woody demography and disturbance-mediated landscape heterogeneity. The } \\
\text { biophysical core (sub-diurnal time-step) consists of four components: (1) the radiation module describes radiation }\end{array}$ \\
\hline
\end{tabular}




\begin{tabular}{|c|c|}
\hline BES-SIM model & Description \\
\hline & $\begin{array}{l}\text { transfer and absorption by sunlit and shaded leaves; (2) the canopy micrometeorology module describes the } \\
\text { surface roughness length, zero-plane displacement height, and aerodynamic conductance from the reference height } \\
\text { to the air within canopy or to the soil surface; (3) the canopy module includes the coupled energy balance, } \\
\text { transpiration, stomatal conductance and photosynthesis and respiration of sunlit and shaded leaves; (4) the soil } \\
\text { module describes heat and water fluxes within soil (6 vertical layers) and snow (up to } 3 \text { vertical layers) and at their } \\
\text { respective surfaces. The CASA-CNP biogeochemistry module (daily time-step) inherits daily net photosynthesis } \\
\text { from the biophysical code, calculates autotrophic respiration, allocates the resulting net primary production (NPP) } \\
\text { to leaves, stems and fine roots, and transfers carbon, nitrogen and phosphorous between plant, litter and soil pools, } \\
\text { accounting for losses of each to the atmosphere and by leaching. POP (annual time-step) inherits annual stem NPP } \\
\text { from CASA-CNP, and simulates patch-scale woody ecosystem stand dynamics, demography and disturbance- } \\
\text { mediated heterogeneity, returning the emergent rate of biomass turnover to CASA-CNP. The model outputs C } \\
\text { pools in veg., soil, GPP, heterotrophic respiration, NPP, runoff, LAI, combined crop and pasture yields, wood } \\
\text { harvest, C:N ratios, either per grid cell simulated, or per PFT. } \\
\text { The land-use and land-cover change module, driven by gross land-use transitions and wood harvest area extend } \\
\text { the applicability of CABLE for regional and global carbon-climate simulations, accounting for vegetation response } \\
\text { of both biophysical and anthropogenic forcing. Land-use transitions and harvest associated with secondary forest } \\
\text { tiles modify the annually-resolved patch age distribution within secondary-vegetated tiles, in turn affecting } \\
\text { biomass accumulation and turnover rates and hence the magnitude of the secondary forest sink. } \\
\text { CABLE incorporates a novel approach to constraining modelled GPP to be consistent with the Co-ordination } \\
\text { Hypothesis, predicted by evolutionary theory, which suggests that electron transport and Rubisco-limited rates } \\
\text { adjust seasonally and across biomes to be co-limiting. }\end{array}$ \\
\hline GLOBIO-ES & $\begin{array}{l}\text { The GLOBIO-ES model (Alkemade et al., 2014; Schulp et al., 2012) simulate the influence of various } \\
\text { anthropogenic drivers on ecosystem functions and services at the global scale in past, present and future } \\
\text { environments using model outcomes of the IMAGE model on food production, livestock production, carbon } \\
\text { balance, land use, and climate (Stehfest et al., 2014), in combination with data on GDP per capita, protected area } \\
\text { maps and infrastructure. For ecosystem services related to water, water flow regimes are derived from the PCR- } \\
\text { GLOBWB model, and nutrient loading is derived from the IMAGE framework model Global Nutrient Model (see } \\
\text { also section on GLOBIO-Aquatic). The model transfers IMAGE model outcomes into a supply - demand concept } \\
\text { of ecosystem services and uses causal relationships between environmental variables and ecosystem functions and } \\
\text { services (definitions according the cascade model by Haines-Young and Potschin (2010) based on literature } \\
\text { reviews). The model quantifies a range of provisioning services (e.g. crop production, grass and fodder production, } \\
\text { wild food, water availability), regulating services (e.g. pest control, pollination, erosion risk reduction, carbon } \\
\text { sequestration, food risk reduction, harmful algal blooms), and culture services (e.g. nature based tourism) These } \\
\text { relationships describe how ecosystem services respond to changing environments. The improvements made since } \\
\text { last published methodology include updated relationships between land use and the presence of pollinators and } \\
\text { predators using additional peer review papers. }\end{array}$ \\
\hline InVEST & $\begin{array}{l}\text { Nutrient Delivery Ratio } \\
\text { The InVEST nutrient delivery ratio model (Redhead et al., 2018) maps nutrient sources from watersheds and their } \\
\text { transport to the stream using digital elevation model, land-use land-cover data, nutrient runoff proxy, watersheds } \\
\text { layer, and biophysical table. This spatial information can be used to assess the service of nutrient retention by } \\
\text { natural vegetation. The retention service is of particular interest for surface water quality issues and can be valued } \\
\text { in economic or social terms (e.g. avoided treatment costs, improved water security through access to clean } \\
\text { drinking water). The model uses a mass balance approach, describing the movement of mass of nutrient through } \\
\text { space. Unlike more sophisticated nutrient models, the model does not represent the details of the nutrient cycle but } \\
\text { rather represents the long-term, steady-state flow of nutrients through empirical relationships. Sources of nutrient } \\
\text { across the landscape, also called nutrient loads, are determined based on the LULC map and associated loading } \\
\text { rates. In a second step, delivery factors are computed for each pixel based on the properties of pixels belonging to } \\
\text { the same flow path (in particular their slope and retention efficiency of the land use). At the } \\
\text { watershed/subwatershed outlet, the nutrient export is computed as the sum of the pixel-level contributions. The } \\
\text { model outputs total nutrient loads (sources) in the watershed and total nutrient exports from the water shed at the } \\
\text { pixel level. Improvements were made to the model to accept load as a raster for certain LULC classes (agriculture) }\end{array}$ \\
\hline
\end{tabular}




\begin{tabular}{|c|c|}
\hline BES-SIM model & Description \\
\hline & 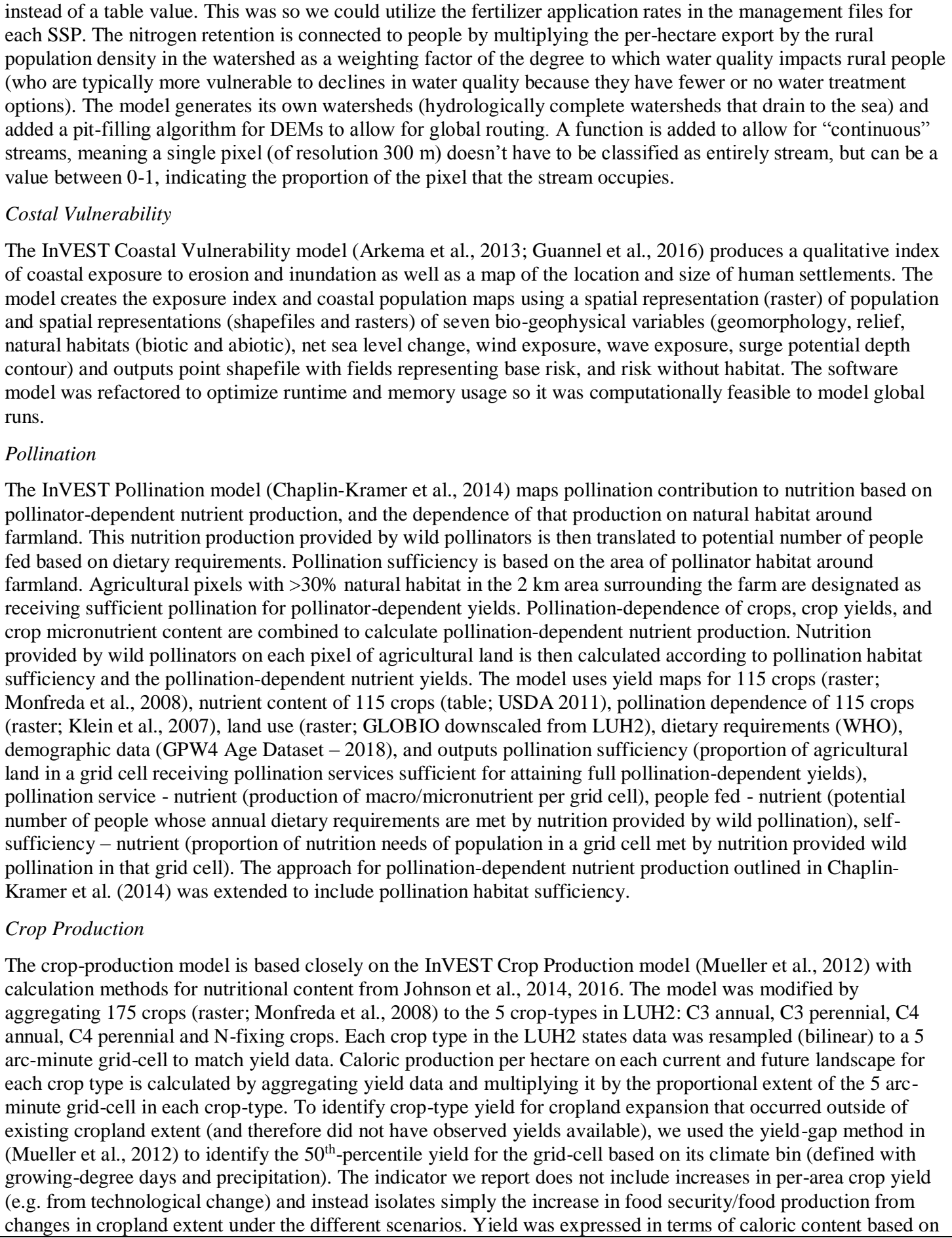 \\
\hline
\end{tabular}




\begin{tabular}{|l|l|}
\hline BES-SIM model & Description \\
\hline GLOSP & $\begin{array}{l}\text { aggregated-versions of the food balance sheets of the Food and Agriculture Organization of the United Nations } \\
\text { FAOSTAT database. }\end{array}$ \\
\hline $\begin{array}{l}\text { GLOSP (Guerra et al., 2016) is a 2D soil erosion model based on the Universal Soil Loss Equation, using climate, } \\
\text { land use, vegetation cover, topography, and soil data to estimate global and local soil erosion and protection } \\
\text { indicators. Protected soil (Ps) is defined as the amount of soil that is prevented from being eroded (water erosion) } \\
\text { by the mitigating effect of available vegetation. Ps is calculated from the difference between soil erosion (Se) and } \\
\text { potential soil erosion (Pse) [Ps = Pse-Se]. Pse is calculated by the integration of the joint effect of slope length, } \\
\text { rainfall erosivity, and soil erodibility. Se is calculated by multiplying Pse by the fractional vegetation cover (0 }\end{array}$ \\
$\begin{array}{l}\text { Fcover } \leq 1) \text {. Here soil protection is given by the value of fractional vegetation cover calculated as a function of } \\
\text { land use, altitude, precipitation, and soil properties. Global fractional vegetation cover is originally calculated } \\
\text { based on a multiple endmembers method described in Filiponi et al. (accepted). This is then resampled to 0.25 } \\
\text { degree. To obtain a long temporal distribution of this variable (1900-2099), a spatial explicit polynomial } \\
\text { regression function is implemented to calculate monthly Fcover values as a function of land use, altitude, } \\
\text { precipitation, and soil properties. For future conditions, vegetation values are calculated based on SSP RCP } \\
\text { correspondences. An assumption is made to the historical projections that the physical processes remain the same } \\
\text { through time. }\end{array}$ \\
\hline
\end{tabular}


Table S3: Definition of metrics in ecosystem functions and services models in BES-SIM.

\begin{tabular}{|c|c|c|c|c|c|}
\hline $\begin{array}{l}\text { Types of } \\
\text { services }\end{array}$ & $\mathrm{NCP}$ & Metric & Models & Units & Definitions and formula \\
\hline Material & Energy & $\begin{array}{l}\text { Bioenergy-crop } \\
\text { Production }\end{array}$ & LPJ-GUESS & $\begin{array}{l}\mathrm{PgC} / \mathrm{yr} \\
\mathrm{kgC} / \mathrm{m}^{2} / \mathrm{yr}\end{array}$ & $\begin{array}{l}\text { First generation biofuel crop production (carbon removed } \\
\text { during harvest) }\end{array}$ \\
\hline Material & Food and feed & Crop Yields & LPJ-GUESS & $\begin{array}{l}\mathrm{PgC} / \mathrm{yr} \\
\mathrm{kgC} / \mathrm{m}^{2} / \mathrm{yr}\end{array}$ & $\begin{array}{l}\text { Harvested carbon in croplands that are used for food production } \\
\text { (excluding pastures) }\end{array}$ \\
\hline Material & Food and feed & $\begin{array}{l}\text { Crop and Pasture } \\
\text { Yield }\end{array}$ & CABLE & $\begin{array}{l}\mathrm{PgC} / \mathrm{yr} \\
\mathrm{kgC} / \mathrm{m}^{2} / \mathrm{yr}\end{array}$ & $\begin{array}{l}\text { Above ground carbon removed from cropland and pastures as a } \\
\text { result of harvest and grazing }\end{array}$ \\
\hline Material & Food and feed & Crop Production & GLOBIO-ES & $10^{9} \mathrm{KCal}$ & $\begin{array}{l}\text { The total crop production derived by applying crop } \\
\text { productivity of the IMAGE model on the LUH2 crop area } \\
\text { estimates, and is derived from the total human demand } \\
\text { (including for livestock); production of various crop categories, } \\
\text { including wheat, rice, maize, tubers, pulses etc. using estimates } \\
\text { of average caloric content the production was translated into } \\
\text { Kcal produced. }\end{array}$ \\
\hline Material & Food and feed & Grass Production & GLOBIO-ES & Gcal & $\begin{array}{l}\text { Grass and fodder production derived by applying grass } \\
\text { productivity from the IMAGE model on the LUH2 grassland } \\
\text { area estimates; production derived from the total demand of } \\
\text { livestock production; largely from pastures and rangelands. }\end{array}$ \\
\hline Material & Food and feed & $\begin{array}{l}\text { Production of } \\
\text { C3Nfx, C3Ann, } \\
\text { C3Per, C4Ann, } \\
\text { C4Per }\end{array}$ & InVEST & kcal & $\begin{array}{l}\text { Caloric production on the current landscape for each crop type } \\
\text { - crop yields based on Monfreda et al. (2008); kcals calculated } \\
\text { based on FAO food-balance sheets (FAO 2017) }\end{array}$ \\
\hline Material & $\begin{array}{l}\text { Materials, } \\
\text { companionship } \\
\text { and labor }\end{array}$ & Wood Harvest & $\begin{array}{l}\text { LPJ-GUESS, } \\
\text { CABLE }\end{array}$ & $\begin{array}{l}\mathrm{KgC}, \mathrm{PgC} / \mathrm{yr} \\
\mathrm{kgC} / \mathrm{m}^{2} / \mathrm{yr}\end{array}$ & $\begin{array}{l}\text { Wood carbon removed from natural vegetation (driven by } \\
\text { wood harvest fraction from LUH2) }\end{array}$ \\
\hline Regulating & $\begin{array}{l}\text { Pollination and } \\
\text { dispersal of } \\
\text { seeds and other } \\
\text { propagules }\end{array}$ & $\begin{array}{l}\text { Pollination: fraction } \\
\text { of cropland } \\
\text { potentially } \\
\text { pollinated, relative } \\
\text { to all available } \\
\text { cropland }\end{array}$ & GLOBIO-ES & Proportion & $\begin{array}{l}\text { Pollination by natural pollinators assumed to be more effective } \\
\text { in cropland situated near natural land; pollination efficiency } \\
\text { related to distance from natural elements, based on literature } \\
\text { review. } \\
\text { A consequence is that pollination increases with the fraction of } \\
\text { nature in a cell. We use the relationship between pollination } \\
\text { efficiency and the fraction of natural area within a cell } 0.5 \text { by } \\
0.5 \text { degrees (Schulp et al., 2012). } \\
\text { If NatPerc }>20 \text { and NatPerc }<60 \text {, then pollination efficiency = } \\
0.25 * \text { NatPerc }+85 \text {, else pollination efficiency = } 100 \\
\text { Sum: Total cropland potentially pollinated }\end{array}$ \\
\hline Regulating & $\begin{array}{l}\text { Pollination and } \\
\text { dispersal of } \\
\text { seeds and other } \\
\text { propagules }\end{array}$ & $\begin{array}{l}\text { Pollination: } \\
\text { proportion of } \\
\text { agricultural lands } \\
\text { whose pollination } \\
\text { needs are met }\end{array}$ & InVEST & Proportion & $\begin{array}{l}\text { The model maps pollination contribution to nutrition based on } \\
\text { proportion of crop production that is dependent on pollination, } \\
\text { and proportion of that production whose pollination needs are } \\
\text { met by natural habitat around farmland. }\end{array}$ \\
\hline
\end{tabular}




\begin{tabular}{|c|c|c|c|c|c|}
\hline $\begin{array}{l}\text { Types of } \\
\text { services }\end{array}$ & $\mathrm{NCP}$ & Metric & Models & Units & Definitions and formula \\
\hline Regulating & $\begin{array}{l}\text { Regulation of } \\
\text { climate }\end{array}$ & Total Carbon & $\begin{array}{l}\text { LPJ-GUESS, } \\
\text { LPJ, CABLE }\end{array}$ & $\mathrm{PgC}, \mathrm{kgC} / \mathrm{m}^{2}$ & $\begin{array}{l}\text { Sum of vegetation, litter and soil carbon stocks; total carbon } \\
\text { pool in the ecosystem, including carbon in stems, branches, } \\
\text { leaves, roots, soil and litter }\end{array}$ \\
\hline Regulating & $\begin{array}{l}\text { Regulation of } \\
\text { climate }\end{array}$ & Total Carbon & GLOBIO-ES & $\mathrm{MgC}$ & $\begin{array}{l}\text { Total carbon pool in the ecosystem, including carbon in stems, } \\
\text { branches, leaves, roots, soil and litter, derived from the IMAGE } \\
\text { model (using LPJmL) }\end{array}$ \\
\hline Regulating & $\begin{array}{l}\text { Regulation of } \\
\text { climate }\end{array}$ & Vegetation Carbon & $\begin{array}{l}\text { LPJ-GUESS, } \\
\text { LPJ, CABLE }\end{array}$ & $\begin{array}{l}\mathrm{PgC}, \mathrm{kg} / \mathrm{m}^{2} \\
\mathrm{PgC}, \mathrm{kgC} / \mathrm{m}^{2}\end{array}$ & Carbon stocks in living wood, roots and leaves \\
\hline Regulating & $\begin{array}{l}\text { Regulation of } \\
\text { freshwater } \\
\text { quantity, } \\
\text { location and } \\
\text { timing }\end{array}$ & Monthly Runoff & $\begin{array}{l}\text { LPJ-GUESS, } \\
\text { LPJ, CABLE }\end{array}$ & $\begin{array}{l}\mathrm{Pg} / \mathrm{s}, \mathrm{kg} / \mathrm{m}^{2} \mathrm{~s}, \\
\mathrm{Pg} / \mathrm{month}, \\
\mathrm{kg} / \mathrm{m}^{2} \text { month, } \\
\mathrm{Pg} / \mathrm{s}, \mathrm{kg} / \mathrm{m}^{2} / \mathrm{s}\end{array}$ & $\begin{array}{l}\text { Sum of drainage, surface and base waterflow } \\
\text { Maximum monthly runoff - monthly combined surface and } \\
\text { subsurface runoff summed }\end{array}$ \\
\hline Regulating & $\begin{array}{l}\text { Regulation of } \\
\text { freshwater } \\
\text { quantity, } \\
\text { location and } \\
\text { timing }\end{array}$ & Total Runoff & CABLE & $\mathrm{km}^{3} / \mathrm{yr}, \mathrm{mm} / \mathrm{yr}$ & Total surface and subsurface runoff summed over the year \\
\hline Regulating & $\begin{array}{l}\text { Regulation of } \\
\text { freshwater } \\
\text { quantity, } \\
\text { location and } \\
\text { timing }\end{array}$ & $\begin{array}{l}\text { Water Scarcity } \\
\text { Index }\end{array}$ & GLOBIO-ES & & $\begin{array}{l}\text { Ratio demand / availability of renewable water, monthly- } \\
\text { weighted }(0-1) \text { (Wada and Bierkens, 2014) }\end{array}$ \\
\hline Regulating & $\begin{array}{l}\text { Regulation of } \\
\text { freshwater and } \\
\text { coastal water } \\
\text { quality }\end{array}$ & Nitrogen Leaching & LPJ-GUESS & $\begin{array}{l}\mathrm{PgN} / \mathrm{s} \\
\mathrm{kgN} / \mathrm{m}^{2} \mathrm{~s}\end{array}$ & $\begin{array}{l}\text { Nitrogen lost from the grid-cell, after subtracting an estimate } \\
\text { for gaseous } \mathrm{N} \text { losses }\end{array}$ \\
\hline Regulating & $\begin{array}{l}\text { Regulation of } \\
\text { freshwater and } \\
\text { coastal water } \\
\text { quality }\end{array}$ & Nitrogen in Water & GLOBIO-ES & $\mathrm{mgN} / \mathrm{l}$ & $\begin{array}{l}\text { Total } \mathrm{N} \text { concentration in the water, i.e. emissions divided by } \\
\text { water discharge. The emissions are the sum of urban and } \\
\text { diffuse sources, accumulated over the upstream catchment of a } \\
\text { cell. The retention in the water network is accounted for } \\
\text { Nitrogen concentration in water [mgN/l] per cell, means and } \\
\text { quartiles per region. }\end{array}$ \\
\hline Regulating & $\begin{array}{l}\text { Regulation of } \\
\text { freshwater and } \\
\text { coastal water } \\
\text { quality }\end{array}$ & $\begin{array}{l}\text { Phosphorous in } \\
\text { Water }\end{array}$ & GLOBIO-ES & $\mathrm{mgN} / 1$ & $\begin{array}{l}\text { Total P concentration in the water, i.e. emissions divided by } \\
\text { water discharge. The emissions are the sum of urban and } \\
\text { diffuse sources, accumulated over the upstream catchment of a } \\
\text { cell. The retention in the water network is accounted for } \\
\text { Phosphorus concentration in water [mgP/l] per cell, means and } \\
\text { quartiles per region. }\end{array}$ \\
\hline
\end{tabular}




\begin{tabular}{|c|c|c|c|c|c|}
\hline $\begin{array}{l}\text { Types of } \\
\text { services }\end{array}$ & $\mathrm{NCP}$ & Metric & Models & Units & Definitions and formula \\
\hline Regulating & $\begin{array}{l}\text { Regulation of } \\
\text { freshwater and } \\
\text { coastal water } \\
\text { quality }\end{array}$ & Nitrogen Export & InVEST & Tons N/year & $\begin{array}{l}\text { The model maps nutrient sources from watersheds and their } \\
\text { transport to the stream. This spatial information can be used to } \\
\text { assess the service of nutrient retention by natural vegetation. } \\
\text { The retention service is of particular interest for surface water } \\
\text { quality issues and can be valued in economic or social terms } \\
\text { (e.g. avoided treatment costs, improved water security through } \\
\text { access to clean drinking water). }\end{array}$ \\
\hline Regulating & $\begin{array}{l}\text { Regulation of } \\
\text { freshwater and } \\
\text { coastal water } \\
\text { quality }\end{array}$ & $\begin{array}{l}\text { Nitrogen } \\
\text { Export*Capita }\end{array}$ & InVEST & $\begin{array}{l}\text { Tons } \\
\mathrm{N}^{*} \text { people } \\
\text { /year }\end{array}$ & $\begin{array}{l}\text { Nitrogen export times rural population, as an indication of } \\
\text { where people are most vulnerable to changes in drinking water } \\
\text { quality, because rural communities typically have fewer water } \\
\text { treatment options or use well-water that may show similar } \\
\text { patterns of nitrate leaching. }\end{array}$ \\
\hline Regulating & $\begin{array}{l}\text { Formation, } \\
\text { protection and } \\
\text { decontamination } \\
\text { of soils and } \\
\text { sediments }\end{array}$ & $\begin{array}{l}\text { Erosion Protection: } \\
\text { fraction with low } \\
\text { risk relative to the } \\
\text { area that needs } \\
\text { protection }\end{array}$ & GLOBIO-ES & index $(0-100)$ & $\begin{array}{l}\text { Erosion risk calculation for pasture, rangeland, cropland and } \\
\text { urban from the USLE as implemented in the IMAGE model. } \\
\text { Based on soil characteristics (e.g. texture, depths and slope), } \\
\text { climate characteristics (e.g. precipitation) and land-use } \\
\text { sensitivity. } \\
\text { The risk is calculated as a relative figure between } 0 \text { and } 100 \text {, } \\
\text { from high to low risk. } \\
\text { Sum: total area with low risk (ER > 80) }\end{array}$ \\
\hline Regulating & $\begin{array}{l}\text { Formation, } \\
\text { protection and } \\
\text { decontamination } \\
\text { of soils and } \\
\text { sediments }\end{array}$ & Soil Protection & GLOSP & $\%$ & $\begin{array}{l}\text { The amount of vegetation cover (in \%cover) across all pixels } \\
\text { within a specific subset (e.g., global, region ' } x \text { '). } \\
\text { For each observed year, these values vary between } 0 \text { and } 1 \text { and } \\
\text { for the change index negative values represent the rate of } \\
\text { decrease in relation to a reference year. }\end{array}$ \\
\hline Regulating & $\begin{array}{l}\text { Regulation of } \\
\text { hazards and } \\
\text { extreme events }\end{array}$ & $\begin{array}{l}\text { Flood Risk: number } \\
\text { of people exposed } \\
\text { to river flood risk }\end{array}$ & GLOBIO-ES & $\begin{array}{l}\text { people } \\
\text { affected }\end{array}$ & $\begin{array}{l}\text { The number of people exposed to river flood risk calculated } \\
\text { based on the frequency of daily river discharge exceeding the } \\
\text { river's capacity, the potentially inundated area and the } \\
\text { population density in that area. 'Normal' predictable yearly } \\
\text { flooding is left out. } \\
\text { Sum = number of people affected, per region }\end{array}$ \\
\hline Regulating & $\begin{array}{l}\text { Regulation of } \\
\text { hazards and } \\
\text { extreme events }\end{array}$ & $\begin{array}{l}\text { Coastal } \\
\text { Vulnerability Index }\end{array}$ & InVEST & $\begin{array}{l}\text { unitless score } \\
\text { from } 1(\min ) \\
\text { to } 5(\max )\end{array}$ & $\begin{array}{l}\text { Geophysical and natural habitat characteristics of coastlines are } \\
\text { used to compare relative exposure to erosion and flooding in } \\
\text { severe weather across space and different scenarios (Arkema et } \\
\text { al., 2013). }\end{array}$ \\
\hline Regulating & $\begin{array}{l}\text { Regulation of } \\
\text { hazards and } \\
\text { extreme events }\end{array}$ & $\begin{array}{l}\text { Coastal } \\
\text { Vulnerability } \\
\text { *Capita }\end{array}$ & InVEST & $\begin{array}{l}\text { unitless } \\
\text { score*people }\end{array}$ & $\begin{array}{l}\text { Total exposure risk times population within } 2 \mathrm{~km} \text { of shore. } \\
\text { When overlaid with data on coastal population density, the } \\
\text { model's outputs can be used to identify where humans face } \\
\text { higher risks of damage from storm waves and surge. }\end{array}$ \\
\hline
\end{tabular}




\begin{tabular}{|l|l|l|l|l|l|}
\hline $\begin{array}{l}\text { Types of } \\
\text { services }\end{array}$ & NCP & Metric & Models & Units \\
\hline Regulating & $\begin{array}{l}\text { Regulation of } \\
\text { detrimental } \\
\text { organisms and } \\
\text { biological } \\
\text { processes }\end{array}$ & $\begin{array}{l}\text { Pest Control: } \\
\text { fraction of cropland } \\
\text { potentially } \\
\text { protected, relative to } \\
\text { all available } \\
\text { cropland }\end{array}$ & GLOBIO-ES & $\mathrm{km}^{2}$ & $\begin{array}{l}\text { Cropland area that is potentially covered by sufficient pest } \\
\text { predators. Pest control by natural predators is assumed to be } \\
\text { more effective in cropland situated near natural land. The pest } \\
\text { control efficiency is related to distance from natural elements, } \\
\text { relation is based on literature review. } \\
\text { A consequence is that pollination increases with the fraction of } \\
\text { nature in a cell. We use the relationship between pollination } \\
\text { efficiency and the fraction of natural area within a cell } 0.5 \text { by } \\
0.5 \text { degrees (Schulp et al., 2012). } \\
\text { If NatPerc < 35, then pest control }=0.48 * \text { NatPerc }+12,75, \\
\text { else pest control }=0.67 * \text { NatPerc }+7.25 \\
\text { Sum: Total cropland potentially covered by natural predators }\end{array}$ \\
\hline
\end{tabular}




\section{References}

Alkemade, R., van Oorschot, M., Miles, L., Nellemann, C., Bakkenes, M. and ten Brink, B.: GLOBIO3: A Framework to Investigate Options for Reducing Global Terrestrial Biodiversity Loss, Ecosystems, 12(3), 374-390, doi:10.1007/s100215 009-9229-5, 2009.

Alkemade, R., Burkhard, B., Crossman, N. D., Nedkov, S. and Petz, K.: Quantifying ecosystem services and indicators for science, policy and practice, Ecol. Indic., 37, 161-162, doi:10.1016/j.ecolind.2013.11.014, 2014.

Allen, L. H., De Benoist, B., Dary, O., Hurrell, R.: World Health Organization: Guidelines on food fortification with micronutrients, 2006.

10 Allnutt, T. F., Ferrier, S., Manion, G., Powell, G. V. N., Ricketts, T. H., Fisher, B. L., Harper, G. J., Irwin, M. E., Kremen, C., Labat, J.-N., Lees, D. C., Pearce, T. A. and Rakotondrainibe, F.: A method for quantifying biodiversity loss and its application to a 50-year record of deforestation across Madagascar: Extinction estimates in Madagascar from deforestation, Conserv. Lett., 1(4), 173-181, doi:10.1111/j.1755-263X.2008.00027.x, 2008.

Arkema, K. K., Guannel, G., Verutes, G., Wood, S. A., Guerry, A., Ruckelshaus, M., Kareiva, P., Lacayo, M. and Silver, J.

15 M.: Coastal habitats shield people and property from sea-level rise and storms, Nat. Clim. Change, 3(10), 913-918, doi:10.1038/nclimate1944, 2013.

Bateman, B. L., Murphy, H. T., Reside, A. E., Mokany, K., VanDerWal, J. and Thuiller, W. (Eds.): Appropriateness of full-, partial- and no-dispersal scenarios in climate change impact modelling, Divers. Distrib., 19(10), 1224-1234, doi:10.1111/ddi.12107, 2013.

20 Benítez-López, A., Alkemade, R., Schipper, A. M., Ingram, D. J., Verweij, P. A., Eikelboom, J. A. J. and Huijbregts, M. A. J.: The impact of hunting on tropical mammal and bird populations, Science, 356(6334), 180-183, doi:10.1126/science.aaj1891, 2017.

Bijl, D. L., Bogaart, P. W., Kram, T., de Vries, B. J. M. and van Vuuren, D. P.: Long-term water demand for electricity, industry and households, Environ. Sci. Policy, 55, 75-86, doi:10.1016/j.envsci.2015.09.005, 2016.

25 Blois, J. L., Williams, J. W., Fitzpatrick, M. C., Jackson, S. T. and Ferrier, S.: Space can substitute for time in predicting climate-change effects on biodiversity, Proc. Natl. Acad. Sci., 110(23), 9374-9379, doi:10.1073/pnas.1220228110, 2013.

Bren d'Amour, C., Reitsma, F., Baiocchi, G., Barthel, S., Güneralp, B., Erb, K.-H., Haberl, H., Creutzig, F. and Seto, K. C.: Future urban land expansion and implications for global croplands, Proc. Natl. Acad. Sci., 114(34), 8939-8944, doi:10.1073/pnas.1606036114, 2017.

30 Brinsmead, T.S., Smith, K., Hatfield-Dodds, S., Adams, P., Baynes, T., Ferrier, S., Harwood, T., Hayward, J.A., Lennox, J., Marcos Martinez, R., Nolan, M., Qiu, J.: A novel integrated assessment framework for exploring possible futures for Australia: the GNOME.3 suite for the Australian National Outlook, in MODSIM2017 (eds), Syme, G., Hatton MacDonald, D., Fulton, B. and Piantadosi, J., 22nd International Congress on Modelling and Simulation. Modelling and Simulation Society of Australia and New Zealand, pp. 1440-1446, 2017.

35 British Nutrition Foundation: Nutrition requirements,

https://www.nutrition.org.uk/attachments/article/234/Nutrition\%20Requirements_Revised\%200ct\%202016.pdf, last access: January 2018.

Brown, J. H., Gillooly, J. F., Allen, A. P., Savage, V. M. and West, G. B.: TOWARD A METABOLIC THEORY OF ECOLOGY, Ecology, 85(7), 1771-1789, doi:10.1890/03-9000, 2004.

40 Bryan, B. A., Nolan, M., Harwood, T. D., Connor, J. D., Navarro-Garcia, J., King, D., Summers, D. M., Newth, D., Cai, Y., Grigg, N., Harman, I., Crossman, N. D., Grundy, M. J., Finnigan, J. J., Ferrier, S., Williams, K. J., Wilson, K. A., Law, E. A. and Hatfield-Dodds, S.: Supply of carbon sequestration and biodiversity services from Australia's agricultural land under global change, Glob. Environ. Change, 28, 166-181, doi:10.1016/j.gloenvcha.2014.06.013, 2014. 
Busch, J. and Ferretti-Gallon, K.: What Drives Deforestation and What Stops It? A Meta-Analysis, Rev. Environ. Econ. Policy, 11(1), 3-23, doi:10.1093/reep/rew013, 2017.

Chaplin-Kramer, R., Dombeck, E., Gerber, J., Knuth, K. A., Mueller, N. D., Mueller, M., Ziv, G. and Klein, A.-M.: Global malnutrition overlaps with pollinator-dependent micronutrient production, Proc. R. Soc. B Biol. Sci., 281(1794), 20141799-

5 20141799, doi:10.1098/rspb.2014.1799, 2014.

Chaudhary, A., Verones, F., de Baan, L. and Hellweg, S.: Quantifying Land Use Impacts on Biodiversity: Combining Species-Area Models and Vulnerability Indicators, Environ. Sci. Technol., 49(16), 9987-9995, doi:10.1021/acs.est.5b02507, 2015.

Denno, R.F., Lewis, D.: Predator-prey interactions: in, The Princeton guide to ecology, Levin, SA, Carpenter, S.R., Godfray, 10 H.C.J., Kinzig, A.P., Loreau, M., et al., Princeton, NJ: Princeton University Press, pp. 202-212, 2012.

Deutsch, C. A., Tewksbury, J. J., Huey, R. B., Sheldon, K. S., Ghalambor, C. K., Haak, D. C. and Martin, P. R.: Impacts of climate warming on terrestrial ectotherms across latitude, Proc. Natl. Acad. Sci., 105(18), 6668-6672, doi:10.1073/pnas.0709472105, 2008.

Döll, P. and Lehner, B.: Validation of a new global 30-min drainage direction map, J. Hydrol., 258(1-4), 214-231,

15 doi:10.1016/S0022-1694(01)00565-0, 2002.

Fekete, B. M., Wisser, D., Kroeze, C., Mayorga, E., Bouwman, L., Wollheim, W. M. and Vörösmarty, C.: Millennium Ecosystem Assessment scenario drivers (1970-2050): Climate and hydrological alterations: GLOBAL NEWS HYDROLOGY, Glob. Biogeochem. Cycles, 24(4), n/a-n/a, doi:10.1029/2009GB003593, 2010.

Ferrier, S., Harwood, T.D., Williams, K.J.: Assessing refugial potential using compositional-turnover modelling, Pages 51-

20 76, in: Climate change refugia for terrestrial biodiversity: defining areas that promote species persistence and ecosystem resilience in the face of global climate change, National Climate Change Adaptation Research Facility, Gold Coast, 2013.

Ferrier, S., Powell, G. V. N., Richardson, K. S., Manion, G., Overton, J. M., Allnutt, T. F., Cameron, S. E., Mantle, K., Burgess, N. D., Faith, D. P., Lamoreux, J. F., Kier, G., Hijmans, R. J., Funk, V. A., Cassis, G. A., Fisher, B. L., Flemons, P., Lees, D., Lovett, J. C. and Van Rompaey, R. S. A. R.: Mapping More of Terrestrial Biodiversity for Global Conservation

25 Assessment, BioScience, 54(12), 1101, doi:10.1641/0006-3568(2004)054[1101:MMOTBF]2.0.CO;2, 2004.

Ferrier, S., Manion, G., Elith, J. and Richardson, K.: Using generalized dissimilarity modelling to analyse and predict patterns of beta diversity in regional biodiversity assessment, Divers. Distrib., 13(3), 252-264, doi:10.1111/j.14724642.2007.00341.x, 2007.

Filipponi F., Valentini E., Xuan A., Guerra C.A., Wolf F., Andrzejak M., Taramelli A.: Global MODIS Fraction

30 of green vegetation Cover for monitoring vegetation abrupt and gradual changes, Remote Sensing. [accepted]

Fitzpatrick, M. C., Sanders, N. J., Ferrier, S., Longino, J. T., Weiser, M. D. and Dunn, R.: Forecasting the future of biodiversity: a test of single- and multi-species models for ants in North America, Ecography, 34(5), 836-847, doi:10.1111/j.1600-0587.2011.06653.x, 2011.

Frischknecht R., Jolliet O. (eds): Global Guidance for Life Cycle Impact Assessment Indicators, vol 1, United Nations

35 Environment Programme, 2016.

Food and Agriculture Organization of the United Nations: Food balance sheets, Rome, http://www.fao.org/economic/ess/fbs/en, 2017.

Food and Agriculture Organization of the United Nations: Global Forest Resources Assessment 2000, Rome, FAO Forestry Department, 2000.

40 Gray, C. L., Hill, S. L. L., Newbold, T., Hudson, L. N., Börger, L., Contu, S., Hoskins, A. J., Ferrier, S., Purvis, A. and Scharlemann, J. P. W.: Local biodiversity is higher inside than outside terrestrial protected areas worldwide, Nat. Commun., 7, 12306, doi:10.1038/ncomms12306, 2016. 
Guannel, G., Arkema, K., Ruggiero, P., Verutes, G. and Bianchi, C. N. (Eds.): The Power of Three: Coral Reefs, Seagrasses and Mangroves Protect Coastal Regions and Increase Their Resilience, PLOS ONE, 11(7), e0158094,

doi:10.1371/journal.pone.0158094, 2016.

Guerra, C. A., Maes, J., Geijzendorffer, I. and Metzger, M. J.: An assessment of soil erosion prevention by vegetation in

5 Mediterranean Europe: Current trends of ecosystem service provision, Ecol. Indic., 60, 213-222,

doi:10.1016/j.ecolind.2015.06.043, 2016.

Haberl, H., Erb, K. H., Krausmann, F., Gaube, V., Bondeau, A., Plutzar, C., Gingrich, S., Lucht, W. and Fischer-Kowalski, M.: Quantifying and mapping the human appropriation of net primary production in earth's terrestrial ecosystems, Proc. Natl. Acad. Sci., 104(31), 12942-12947, doi:10.1073/pnas.0704243104, 2007.

10 Haines-Young, R., Potschin, M.: The links between biodiversity, ecosystem services and human well-being, Ch 7: in, Ecosystem Ecology: A New Synthesis (eds.), Raffaelli, D., Frid, C., BES Ecological Reviews Series, CUP, Cambridge, in press, 2010.

Harfoot, M. B. J., Newbold, T., Tittensor, D. P., Emmott, S., Hutton, J., Lyutsarev, V., Smith, M. J., Scharlemann, J. P. W., Purves, D. W., Loreau, M. (Eds.): Emergent Global Patterns of Ecosystem Structure and Function from a Mechanistic

15 General Ecosystem Model, PLoS Biol., 12(4), e1001841, doi:10.1371/journal.pbio.1001841, 2014.

Hasegawa, T., Fujimori, S., Ito, A., Takahashi, K. and Masui, T.: Global land-use allocation model linked to an integrated assessment model, Sci. Total Environ., 580, 787-796, doi:10.1016/j.scitotenv.2016.12.025, 2017.

Hatfield-Dodds, S., Schandl, H., Adams, P. D., Baynes, T. M., Brinsmead, T. S., Bryan, B. A., Chiew, F. H. S., Graham, P. W., Grundy, M., Harwood, T., McCallum, R., McCrea, R., McKellar, L. E., Newth, D., Nolan, M., Prosser, I. and Wonhas,

20 A.: Australia is 'free to choose' economic growth and falling environmental pressures, Nature, 527(7576), 49-53, doi:10.1038/nature16065, 2015.

Haverd, V., Smith, B., Nieradzik, L., Briggs, P. R., Woodgate, W., Trudinger, C. M. and Canadell, J. G.: A new version of the CABLE land surface model (Subversion revision r4546), incorporating land use and land cover change, woody vegetation demography and a novel optimisation-based approach to plant coordination of electron transport and carboxylation capacity-limited photosynthesis, Geosci. Model Dev. Discuss., 1-33, doi:10.5194/gmd-2017-265, 2017.

Hengl, T., de Jesus, J. M., MacMillan, R. A., Batjes, N. H., Heuvelink, G. B. M., Ribeiro, E., Samuel-Rosa, A., Kempen, B., Leenaars, J. G. B., Walsh, M. G., Gonzalez, M. R. and Bond-Lamberty, B. (Eds.): SoilGrids1km - Global Soil Information Based on Automated Mapping, PLoS ONE, 9(8), e105992, doi:10.1371/journal.pone.0105992, 2014.

Hoskins, A. J., Bush, A., Gilmore, J., Harwood, T., Hudson, L. N., Ware, C., Williams, K. J. and Ferrier, S.: Downscaling

30 land-use data to provide global 30" estimates of five land-use classes, Ecol. Evol., 6(9), 3040-3055, doi:10.1002/ece3.2104, 2016.

Hoskins, A.J., Harwood, T.D., Ware, C., Williams, K.J., Perry, J.J., Ota, N., Croft, J.R., Yeates, D.K., Jetz, W., Golebiewski, M., Purvis, A., Ferrier, S., 2018. Supporting global biodiversity assessment through high-resolution macroecological modelling: Methodological underpinnings of the BILBI framework. BioRxiv http://biorxiv.org/cgi/content/short/309377v1. [in prep.]

Hudson, L. N., Newbold, T., Contu, S., Hill, S. L. L., Lysenko, I., De Palma, A., Phillips, H. R. P., Senior, R. A., Bennett, D. J., Booth, H., Choimes, A., Correia, D. L. P., Day, J., Echeverría-Londoño, S., Garon, M., Harrison, M. L. K., Ingram, D. J., Jung, M., Kemp, V., Kirkpatrick, L., Martin, C. D., Pan, Y., White, H. J., Aben, J., Abrahamczyk, S., Adum, G. B., AguilarBarquero, V., Aizen, M. A., Ancrenaz, M., Arbeláez-Cortés, E., Armbrecht, I., Azhar, B., Azpiroz, A. B., Baeten, L., Báldi,

40 A., Banks, J. E., Barlow, J., Batáry, P., Bates, A. J., Bayne, E. M., Beja, P., Berg, Å., Berry, N. J., Bicknell, J. E., Bihn, J. H., Böhning-Gaese, K., Boekhout, T., Boutin, C., Bouyer, J., Brearley, F. Q., Brito, I., Brunet, J., Buczkowski, G., Buscardo, E., Cabra-García, J., Calviño-Cancela, M., Cameron, S. A., Cancello, E. M., Carrijo, T. F., Carvalho, A. L., Castro, H., CastroLuna, A. A., Cerda, R., Cerezo, A., Chauvat, M., Clarke, F. M., Cleary, D. F. R., Connop, S. P., D’Aniello, B., da Silva, P. G., Darvill, B., Dauber, J., Dejean, A., Diekötter, T., Dominguez-Haydar, Y., Dormann, C. F., Dumont, B., Dures, S. G.,

45 Dynesius, M., Edenius, L., Elek, Z., Entling, M. H., Farwig, N., Fayle, T. M., Felicioli, A., Felton, A. M., Ficetola, G. F., 
Filgueiras, B. K. C., Fonte, S. J., Fraser, L. H., Fukuda, D., Furlani, D., Ganzhorn, J. U., Garden, J. G., Gheler-Costa, C., Giordani, P., Giordano, S., Gottschalk, M. S., Goulson, D., et al.: The PREDICTS database: a global database of how local terrestrial biodiversity responds to human impacts, Ecol. Evol., 4(24), 4701-4735, doi:10.1002/ece3.1303, 2014.

Hudson, L. N., Newbold, T., Contu, S., Hill, S. L. L., Lysenko, I., et al.: Dataset: The 2016 release of the PREDICTS database, http://dx.doi.org/10.5519/0066354, 2016.

Hudson, L. N., Newbold, T., Contu, S., Hill, S. L. L., Lysenko, I., De Palma, A., Phillips, H. R. P., Alhusseini, T. I., Bedford, F. E., Bennett, D. J., Booth, H., Burton, V. J., Chng, C. W. T., Choimes, A., Correia, D. L. P., Day, J., EcheverríaLondoño, S., Emerson, S. R., Gao, D., Garon, M., Harrison, M. L. K., Ingram, D. J., Jung, M., Kemp, V., Kirkpatrick, L., Martin, C. D., Pan, Y., Pask-Hale, G. D., Pynegar, E. L., Robinson, A. N., Sanchez-Ortiz, K., Senior, R. A., Simmons, B. I., 10 White, H. J., Zhang, H., Aben, J., Abrahamczyk, S., Adum, G. B., Aguilar-Barquero, V., Aizen, M. A., Albertos, B., Alcala, E. L., del Mar Alguacil, M., Alignier, A., Ancrenaz, M., Andersen, A. N., Arbeláez-Cortés, E., Armbrecht, I., ArroyoRodríguez, V., Aumann, T., Axmacher, J. C., Azhar, B., Azpiroz, A. B., Baeten, L., Bakayoko, A., Báldi, A., Banks, J. E., Baral, S. K., Barlow, J., Barratt, B. I. P., Barrico, L., Bartolommei, P., Barton, D. M., Basset, Y., Batáry, P., Bates, A. J., Baur, B., Bayne, E. M., Beja, P., Benedick, S., Berg, Å., Bernard, H., Berry, N. J., Bhatt, D., Bicknell, J. E., Bihn, J. H.,

15 Blake, R. J., Bobo, K. S., Bóçon, R., Boekhout, T., Böhning-Gaese, K., Bonham, K. J., Borges, P. A. V., Borges, S. H., Boutin, C., Bouyer, J., Bragagnolo, C., Brandt, J. S., Brearley, F. Q., Brito, I., Bros, V., Brunet, J., Buczkowski, G., Buddle, C. M., Bugter, R., Buscardo, E., Buse, J., Cabra-García, J., Cáceres, N. C., et al.: The database of the PREDICTS (Projecting Responses of Ecological Diversity In Changing Terrestrial Systems) project, Ecol. Evol., 7(1), 145-188, doi:10.1002/ece3.2579, 2017.

20 Hurtt, G. C., Chini, L. P., Frolking, S., Betts, R. A., Feddema, J., Fischer, G., Fisk, J. P., Hibbard, K., Houghton, R. A., Janetos, A., Jones, C. D., Kindermann, G., Kinoshita, T., Klein Goldewijk, K., Riahi, K., Shevliakova, E., Smith, S., Stehfest, E., Thomson, A., Thornton, P., van Vuuren, D. P. and Wang, Y. P.: Harmonization of land-use scenarios for the period 1500-2100: 600 years of global gridded annual land-use transitions, wood harvest, and resulting secondary lands, Clim. Change, 109(1-2), 117-161, doi:10.1007/s10584-011-0153-2, 2011.

25 Hurtt, G., Chini, L., Sahajpal, R., Frolking, S., Calvin, K., Fujimori, S., Klein Goldewijk, K., Hasegawa, T., Havlik, P., Lawrence, D., Lawrence, P., Popp, A., Stehfest, E., van Vuuren, D., and Zhang, X.: Harmonization of global land-use change and management for the period 850-2100. [submitted]

Janse, J. H., Bakkenes, M. \& Meijer, J.: Globio-Aquatic, Technical model description v. 1.3: PBL publication 2829, The Hague, PBL Netherlands Environmental Assessment Agency, 2016.

30 Janse, J. H., Kuiper, J. J., Weijters, M. J., Westerbeek, E. P., Jeuken, M. H. J. L., Bakkenes, M., Alkemade, R., Mooij, W. M. and Verhoeven, J. T. A.: GLOBIO-Aquatic, a global model of human impact on the biodiversity of inland aquatic ecosystems, Environ. Sci. Policy, 48, 99-114, doi:10.1016/j.envsci.2014.12.007, 2015.

Jetz, W., Wilcove, D. S., Dobson, A. P. and Mace, G. M. (Eds.): Projected Impacts of Climate and Land-Use Change on the Global Diversity of Birds, PLoS Biol., 5(6), e157, doi:10.1371/journal.pbio.0050157, 2007.

35 Johnson, J. A., Runge, C. F., Senauer, B., Foley, J. and Polasky, S.: Global agriculture and carbon trade-offs, Proc. Natl. Acad. Sci., 111(34), 12342-12347, doi:10.1073/pnas.1412835111, 2014.

Johnson, J. A., Runge, C. F., Senauer, B. and Polasky, S.: Global Food Demand and Carbon-Preserving Cropland Expansion under Varying Levels of Intensification, Land Econ., 92(4), 579-592, doi:10.3368/le.92.4.579, 2016.

Jones, B. and O’Neill, B. C.: Spatially explicit global population scenarios consistent with the Shared Socioeconomic

40 Pathways, Environ. Res. Lett., 11(8), 084003, doi:10.1088/1748-9326/11/8/084003, 2016.

Klein, A.-M., Vaissiere, B. E., Cane, J. H., Steffan-Dewenter, I., Cunningham, S. A., Kremen, C. and Tscharntke, T.: Importance of pollinators in changing landscapes for world crops, Proc. R. Soc. B Biol. Sci., 274(1608), 303-313, doi:10.1098/rspb.2006.3721, 2007. 
Klein Goldewijk, K., Beusen, A., Doelman, J. and Stehfest, E.: New anthropogenic land use estimates for the Holocene; HYDE 3.2, Earth Syst. Sci. Data Discuss., 1-40, doi:10.5194/essd-2016-58, 2016.

Kourzeneva, E.: External data for lake parameterization in Numerical Weather Prediction and climate modelling, Boreal Environment Research, 15: 165-177, 2010.

5 Lamarque, J.-F., Kyle, G. P., Meinshausen, M., Riahi, K., Smith, S. J., van Vuuren, D. P., Conley, A. J. and Vitt, F.: Global and regional evolution of short-lived radiatively-active gases and aerosols in the Representative Concentration Pathways, Clim. Change, 109(1-2), 191-212, doi:10.1007/s10584-011-0155-0, 2011.

Lehner, B. and Döll, P.: Development and validation of a global database of lakes, reservoirs and wetlands, J. Hydrol., 296(1-4), 1-22, doi:10.1016/j.jhydrol.2004.03.028, 2004.

10 Lehner, B., Liermann, C. R., Revenga, C., Vörösmarty, C., Fekete, B., Crouzet, P., Döll, P., Endejan, M., Frenken, K., Magome, J., Nilsson, C., Robertson, J. C., Rödel, R., Sindorf, N. and Wisser, D.: High-resolution mapping of the world's reservoirs and dams for sustainable river-flow management, Front. Ecol. Environ., 9(9), 494-502, doi:10.1890/100125, 2011.

Lindeskog, M., Arneth, A., Bondeau, A., Waha, K., Seaquist, J., Olin, S. and Smith, B.: Implications of accounting for land 15 use in simulations of ecosystem carbon cycling in Africa, Earth Syst. Dyn., 4(2), 385-407, doi:10.5194/esd-4-385-2013, 2013.

Martins, I. S. and Pereira, H. M.: Improving extinction projections across scales and habitats using the countryside speciesarea relationship, Sci. Rep., 7(1), doi:10.1038/s41598-017-13059-y, 2017.

Meijer, J. R., Huijbregts, M. A. J., Schotten, K. C. G. J. and Schipper, A. M.: Global patterns of current and future road

20 infrastructure, Environmental Research Letters, 13(6), 064006, doi:10.1088/1748-9326/aabd42, 2018.

Merow, C., Smith, M. J. and Silander, J. A.: A practical guide to MaxEnt for modeling species' distributions: what it does, and why inputs and settings matter, Ecography, 36(10), 1058-1069, doi:10.1111/j.1600-0587.2013.07872.x, 2013.

Midgley, G. F., Hughes, G. O., Thuiller, W. and Rebelo, A. G.: Migration rate limitations on climate change-induced range shifts in Cape Proteaceae, Divers. Htmlent Glyphamp Asciiamp Distrib., 12(5), 555-562, doi:10.1111/j.1366-

25 9516.2006.00273.x, 2006.

Mokany, K., Harwood, T. D., Williams, K. J. and Ferrier, S.: Dynamic macroecology and the future for biodiversity, Glob. Change Biol., 18(10), 3149-3159, doi:10.1111/j.1365-2486.2012.02760.x, 2012.

Monfreda, C., Ramankutty, N. and Foley, J. A.: Farming the planet: 2. Geographic distribution of crop areas, yields, physiological types, and net primary production in the year 2000: GLOBAL CROP AREAS AND YIELDS IN 2000, Glob.

30 Biogeochem. Cycles, 22(1), n/a-n/a, doi:10.1029/2007GB002947, 2008.

Mueller, N. D., Gerber, J. S., Johnston, M., Ray, D. K., Ramankutty, N. and Foley, J. A.: Closing yield gaps through nutrient and water management, Nature, 490(7419), 254-257, doi:10.1038/nature11420, 2012.

Newbold, T., Hudson, L. N., Hill, S. L. L., Contu, S., Lysenko, I., Senior, R. A., Börger, L., Bennett, D. J., Choimes, A., Collen, B., Day, J., De Palma, A., Díaz, S., Echeverria-Londoño, S., Edgar, M. J., Feldman, A., Garon, M., Harrison, M. L.

35 K., Alhusseini, T., Ingram, D. J., Itescu, Y., Kattge, J., Kemp, V., Kirkpatrick, L., Kleyer, M., Correia, D. L. P., Martin, C. D., Meiri, S., Novosolov, M., Pan, Y., Phillips, H. R. P., Purves, D. W., Robinson, A., Simpson, J., Tuck, S. L., Weiher, E., White, H. J., Ewers, R. M., Mace, G. M., Scharlemann, J. P. W. and Purvis, A.: Global effects of land use on local terrestrial biodiversity, Nature, 520(7545), 45-50, doi:10.1038/nature14324, 2015.

Newbold, T., Hudson, L. N., Hill, S. L. L., Contu, S., Gray, C. L., Scharlemann, J. P. W., Börger, L., Phillips, H. R. P., Sheil, 40 D., Lysenko, I. and Purvis, A.: Global patterns of terrestrial assemblage turnover within and among land uses, Ecography, 39(12), 1151-1163, doi:10.1111/ecog.01932, 2016a. 
Newbold, T., Hudson, L. N., Arnell, A. P., Contu, S., De Palma, A., Ferrier, S., Hill, S. L. L., Hoskins, A. J., Lysenko, I., Phillips, H. R. P., Burton, V. J., Chng, C. W. T., Emerson, S., Gao, D., Pask-Hale, G., Hutton, J., Jung, M., Sanchez-Ortiz, K., Simmons, B. I., Whitmee, S., Zhang, H., Scharlemann, J. P. W. and Purvis, A.: Has land use pushed terrestrial biodiversity beyond the planetary boundary? A global assessment, Science, 353(6296), 288-291,

doi:10.1126/science.aaf2201, $2016 \mathrm{~b}$.

Ohashi, H., Hasegawa, T., Hirata, A., Fujimori, S., Takahashi, K., Tsuyama, I., Nakao, K., Kominami, Y., Tanaka, N., Hijioka, Y., Matsui, T.: Biodiversity can benefit from long-term climate mitigation regardless of land-based measures. [submitted]

Olin, S., Schurgers, G., Lindeskog, M., Wårlind, D., Smith, B., Bodin, P., Holmér, J. and Arneth, A.: Modelling the response of yields and tissue $\mathrm{C}: \mathrm{N}$ to changes in atmospheric $\mathrm{CO}_{2}$ and $\mathrm{N}$ management in the main wheat regions of western Europe,

10 Biogeosciences, 12(8), 2489-2515, doi:10.5194/bg-12-2489-2015, 2015.

Pereira, H. M. and Daily, G. C.: Modelling biodiversity dynamics in countryside landscapes, Ecology, 87(8), 1877-1885, doi:10.1890/0012-9658(2006)87[1877:MBDICL]2.0.CO;2, 2006.

Petz, K., Alkemade, R., Bakkenes, M., Schulp, C. J. E., van der Velde, M. and Leemans, R.: Mapping and modelling tradeoffs and synergies between grazing intensity and ecosystem services in rangelands using global-scale datasets and models, Glob. Environ. Change, 29, 223-234, doi:10.1016/j.gloenvcha.2014.08.007, 2014.

Phillips, S. J., Anderson, R. P. and Schapire, R. E.: Maximum entropy modeling of species geographic distributions, Ecol. Model., 190(3-4), 231-259, doi:10.1016/j.ecolmodel.2005.03.026, 2006.

Phillips, S. J., Dudík, M., Elith, J., Graham, C. H., Lehmann, A., Leathwick, J. and Ferrier, S.: Sample selection bias and presence-only distribution models: implications for background and pseudo-absence data, Ecol. Appl., 19(1), 181-197,

20 doi:10.1890/07-2153.1, 2009.

Pletcher: Model fitting and hypothesis testing for age-specific mortality data, J. Evol. Biol., 12(3), 430-439, doi:10.1046/j.1420-9101.1999.00058.x, 1999.

Poulter, B., Frank, D. C., Hodson, E. L. and Zimmermann, N. E.: Impacts of land cover and climate data selection on understanding terrestrial carbon dynamics and the $\mathrm{CO}_{2}$ airborne fraction, Biogeosciences, 8(8), 2027-2036, doi:10.5194/bg25 8-2027-2011, 2011.

Prober, S. M., Hilbert, D. W., Ferrier, S., Dunlop, M. and Gobbett, D.: Combining community-level spatial modelling and expert knowledge to inform climate adaptation in temperate grassy eucalypt woodlands and related grasslands, Biodivers. Conserv., 21(7), 1627-1650, doi:10.1007/s10531-012-0268-4, 2012.

Prober, S.M., Williams, K.J., Harwood, T.D., Doerr, V.A.J., Jeanneret, T., Manion, G., Ferrier, S.: Helping biodiversity 30 adapt: Supporting climate-adaptation planning using a community-level modelling approach, CSIRO Land and Water Flagship, 2015.

Redhead, J. W., May, L., Oliver, T. H., Hamel, P., Sharp, R. and Bullock, J. M.: National scale evaluation of the InVEST nutrient retention model in the United Kingdom, Sci. Total Environ., 610-611, 666-677, doi:10.1016/j.scitotenv.2017.08.092, 2018.

35 Rondinini, C., Di Marco, M., Chiozza, F., Santulli, G., Baisero, D., Visconti, P., Hoffmann, M., Schipper, J., Stuart, S. N., Tognelli, M. F., Amori, G., Falcucci, A., Maiorano, L. and Boitani, L.: Global habitat suitability models of terrestrial mammals, Philos. Trans. R. Soc. B Biol. Sci., 366(1578), 2633-2641, doi:10.1098/rstb.2011.0113, 2011.

Schipper, A.M., Bakkenes, M., Meijer, J.R., Alkemade, R., Huijbregts, M.J.: The GLOBIO model. A technical description of version 3.5. PBL publication 2369, The Hague, PBL Netherlands Environmental Assessment Agency, 2016.

40 Scholes, R. J. and Biggs, R.: A biodiversity intactness index, Nature, 434(7029), 45, 2005.

Schulp, C. J. E., Alkemade, R., Klein Goldewijk, K. and Petz, K.: Mapping ecosystem functions and services in Eastern Europe using global-scale data sets, Int. J. Biodivers. Sci. Ecosyst. Serv. Manag., 8(1-2), 156-168, doi:10.1080/21513732.2011.645880, 2012. 
Sharp, R., Tallis, H.T., Ricketts, T., Guerry, A.D., Wood, S.A., Chaplin-Kramer, R., Nelson, E., Ennaanay, D., Wolny, S., Olwero, N., Vigerstol, K., Pennington, D., Mendoza, G., Aukema, J., Foster, J., Forrest, J., Cameron, D., Arkema, K., Lonsdorf, E., Kennedy, C., Verutes, G., Kim, C.K., Guannel, G., Papenfus, M., Toft, J., Marsik, M., Bernhardt, J., Griffin, R., Glowinski, K., Chaumont, N., Perelman, A., Lacayo, M. Mandle, L., Hamel, P., Vogl, A.L., Rogers, L., Bierbower, W., 5 Denu, D., and Douglass, J.: InVEST +VERSION+ User's Guide, The Natural Capital Project, Stanford University, University of Minnesota, The Nature Conservancy, and World Wildlife Fund, 2018.

Smith, B., Wårlind, D., Arneth, A., Hickler, T., Leadley, P., Siltberg, J. and Zaehle, S.: Implications of incorporating N cycling and $\mathrm{N}$ limitations on primary production in an individual-based dynamic vegetation model, Biogeosciences, 11(7), 2027-2054, doi:10.5194/bg-11-2027-2014, 2014.

10 Smith, M. J., Purves, D. W., Vanderwel, M. C., Lyutsarev, V. and Emmott, S.: The climate dependence of the terrestrial carbon cycle, including parameter and structural uncertainties, Biogeosciences, 10(1), 583-606, doi:10.5194/bg-10-5832013, 2013.

Stehfest, E., van Vuuren, D., Kram, T., Bouwman, L., Alkemade, R., Bakkenes, M., Biemans, H., Bouwman, A., den Elzen, M., Janse, J., Lucas, P., van Minnen, J., Müller, M., Prins, A.: Integrated Assessment of Global Environmental Change with

15 IMAGE 3.0. Model description and policy applications, The Hague: PBL Netherlands Environmental Assessment Agency, 2014.

Temme, A. J. A. M. and Verburg, P. H.: Mapping and modelling of changes in agricultural intensity in Europe, Agric. Ecosyst. Environ., 140(1-2), 46-56, doi:10.1016/j.agee.2010.11.010, 2011.

Thuiller, W.: Patterns and uncertainties of species' range shifts under climate change, Glob. Change Biol., 10(12), 2020-

20 2027, doi:10.1111/j.1365-2486.2004.00859.x, 2004.

Thuiller, W., Lafourcade, B., Engler, R. and Araújo, M. B.: BIOMOD - a platform for ensemble forecasting of species distributions, Ecography, 32(3), 369-373, doi:10.1111/j.1600-0587.2008.05742.x, 2009.

Thuiller, W., Lavergne, S., Roquet, C., Boulangeat, I., Lafourcade, B. and Araujo, M. B.: Consequences of climate change on the tree of life in Europe, Nature, 470(7335), 531-534, doi:10.1038/nature09705, 2011.

25 Tolman, H.L.: User Manual and System Documentation of WAVEWATCH III version 3.14 Technical Note, US Department of Commerce, National Oceanographic and Atmospheric Administration, National Weather Service, National Centers for Environmental Predictions, 2009.

Visconti, P., Bakkenes, M., Baisero, D., Brooks, T., Butchart, S. H. M., Joppa, L., Alkemade, R., Di Marco, M., Santini, L., Hoffmann, M., Maiorano, L., Pressey, R. L., Arponen, A., Boitani, L., Reside, A. E., van Vuuren, D. P. and Rondinini, C.:

30 Projecting Global Biodiversity Indicators under Future Development Scenarios: Projecting biodiversity indicators, Conserv. Lett., 9(1), 5-13, doi:10.1111/conl.12159, 2016.

Wang, Y. P., Law, R. M. and Pak, B.: A global model of carbon, nitrogen and phosphorus cycles for the terrestrial biosphere, Biogeosciences, 7(7), 2261-2282, doi:10.5194/bg-7-2261-2010, 2010.

Williams, K.J., Prober, S.M., Harwood, T.D., Doerr, V.A.J., Jeanneret, T., Manion, G., Ferrier, S.: Implications of climate

35 change for biodiversity: A community-level modelling approach. CSIRO Land and Water Flagship, http://adaptnrm.csiro.au/wp-content/uploads/2014/12/biodiversity-implications-tech-guide.pdf, 2015.

Williams, R. J., Anandanadesan, A., Purves, D. and Bersier, L.-F. (Eds.): The Probabilistic Niche Model Reveals the Niche Structure and Role of Body Size in a Complex Food Web, PLoS ONE, 5(8), e12092, doi:10.1371/journal.pone.0012092, 2010.

40 Zabel, F., Putzenlechner, B., Mauser, W. and Kropp, J. P. (Eds.): Global Agricultural Land Resources - A High Resolution Suitability Evaluation and Its Perspectives until 2100 under Climate Change Conditions, PLoS ONE, 9(9), e107522, doi:10.1371/journal.pone.0107522, 2014. 